\title{
1 The Phenome-wide Consequences of Anorexia Nervosa Genes
}

2 Jessica S. Johnson, MPH ${ }^{1,2}$, Alanna C. Cote ${ }^{1,2}$, Amanda Dobbyn, PhD ${ }^{1-3}$, Laura G. Sloofman, $\mathrm{MS}^{4}$, Jiayi

$3 \mathrm{Xu}, \mathrm{PhD}^{1,2}$, Liam Cotter ${ }^{1,2}$, Alexander W. Charney, MD, $\mathrm{PhD}^{1-3,5,6}$, Eating Disorders Working Group of the

4 Psychiatric Genomics Consortium*, Jennifer Jordan, $\mathrm{PhD}^{7}$, Martin Kennedy, $\mathrm{PhD}^{7}$, Mikael Landén, $\mathrm{MD}$,

$5 \quad \mathrm{PhD}^{8,9}$, Sarah L Maguire, $\mathrm{PhD}^{10}$, Nicholas G Martin, $\mathrm{PhD}^{11}$, Preben Bo Mortensen, MD, DMSc ${ }^{12}$, Cynthia

6 M. Bulik, $\mathrm{PhD}^{9,13,14}$, Laura M. Huckins, $\mathrm{PhD}^{1-6 \dagger}$

$8{ }^{1}$ Pamela Sklar Division of Psychiatric Genomics, Icahn School of Medicine at Mount Sinai, New York, NY 9 10029, USA

$10{ }^{2}$ Department of Genetics and Genomics, Icahn School of Medicine at Mount Sinai, New York, NY 10029, $11 \quad$ USA

$12{ }^{3}$ Icahn Institute for Genomics and Multiscale Biology, Icahn School of Medicine at Mount Sinai, New York, 13 NY 10029, USA

$14{ }^{4}$ Seaver Autism Center for Research and Treatment, Icahn School of Medicine at Mount Sinai, New 15 York, NY 10029, USA

$16{ }^{5}$ Department of Psychiatry, Icahn School of Medicine at Mount Sinai, New York, NY 10029, USA

$17{ }^{6}$ Mental Illness Research, Education and Clinical Centers, James J. Peters Department of Veterans 18 Affairs Medical Center, Bronx, NY 14068, USA

$19{ }^{7}$ University of Otago, Department of Psychological Medicine, Christchurch School of Medicine \& Health

20 Sciences, 2 Riccarton Avenue, PO Box 4345, 8140 Christchurch, New Zealand

$21{ }^{8}$ Gothenburg University, Box 100, SE-405 30 Gothenburg, Sweden

$22{ }^{9}$ Department of Medical Epidemiology and Biostatistics, Karolinska Institute, Stockholm, Sweden

$23{ }^{10}$ School of Medicine, InsideOut Institute, Sydney, New South Wales, 2006, Australia

$24{ }^{11}$ QIMR Berghofer Medical Research Institute, Locked Bag 2000, Royal Brisbane Hospital QLD 4029,

$25 \quad$ Australia

$26{ }^{12}$ Aarhus University, Norde Ringgade 1, 8000 Aarhus, Denmark

$27{ }^{13}$ Department of Psychiatry, University of North Carolina at Chapel Hill, Chapel Hill, NC 27517, USA

$28{ }^{14}$ Department of Nutrition, University of North Carolina at Chapel Hill, Chapel Hill, NC 27517, USA

\footnotetext{
${ }^{*}$ Full list of PGC-ED working group authors is available in the supplementary materials.

† Corresponding author: Dr. Laura M. Huckins, Icahn School of Medicine at Mount Sinai, 1425 Madison Ave., $3^{\text {rd }}$

Floor, Room L3-70i, New York, NY 10029; laura.huckins@mssm.edu, (212) 659-1613.
} 
medRxiv preprint doi: https://doi.org/10.1101/2021.02.12.21250941; this version posted March 13, 2021. The copyright holder for this preprint (which was not certified by peer review) is the author/funder, who has granted medRxiv a license to display the preprint in perpetuity.

It is made available under a CC-BY-NC-ND 4.0 International license .

\section{ABSTRACT}

31 Anorexia nervosa (AN) is a psychiatric disorder with complex etiology, with a significant portion of disease

32 risk imparted by genetics. Traditional GWAS studies produce principal evidence for the association of

33 genetic variants with disease, and provide a jumping-off point for downstream functional analyses.

34 Transcriptomic imputation (TI) allows for the translation of SNPs into regulatory mechanisms, which can

35 then be used to assess the functional outcome of genetically regulated gene expression (GReX) in a

36 more broad setting through the use of phenome-wide association studies (PheWAS) in large and diverse

37 clinical biobank populations with electronic health record (EHR) phenotypes. Here, we applied TI using S-

38 PrediXcan to translate the most recent PGC-ED AN GWAS findings into AN-GReX. For significant genes, 39 we imputed AN-GReX in the Mount Sinai BioMe ${ }^{T M}$ Biobank and performed PheWAS on over 2000 clinical

40 outcomes to test the clinical consequences of aberrant expression of these genes. We performed a

41 secondary analysis to assess the impact of BMI on AN-GReX clinical associations.

43 Our S-PrediXcan analysis identified 47 genes associated with AN, including what is, to our knowledge,

44 the first genetic association of AN with the Major Histocompatibility Complex (MHC). AN-GReX was

45 associated with autoimmune, anthropometric, metabolic, psychiatric and gastrointestinal diagnoses in our

46 biobank cohort, as well as measures of anthropometry, substance use, and pain score. Our analyses

47 reveal that AN-GReX associations with measures of weight and substance use are modified by BMI, and

48 indicate potential avenues of functional mechanism to investigate further. 
medRxiv preprint doi: https://doi.org/10.1101/2021.02.12.21250941; this version posted March 13, 2021. The copyright holder for this preprint (which was not certified by peer review) is the author/funder, who has granted medRxiv a license to display the preprint in perpetuity.

It is made available under a CC-BY-NC-ND 4.0 International license .

\section{INTRODUCTION}

53 Anorexia nervosa (AN) is a severe eating disorder characterized by extreme low body weight and fear of

54 gaining weight, and is often accompanied by compensatory behaviors to lose weight such as dietary

55 restriction, purging, and higher than average physical activity(1). With a lifetime prevalence of $0.9-4 \%$, AN

56 has high mortality, with few effective treatments and an increased risk of suicide(2-4). Clinical and

57 epidemiological studies have shown higher risk of other psychiatric disorders such as OCD, anxiety, and

58 major depression in individuals with $\mathrm{AN}(3,5)$, and higher risk of substance use disorders in AN subtypes

59 (6), as well as higher risk of metabolic and autoimmune disorders such as type 1 diabetes $(7,8)$ '. Twin

60 studies have established the heritability of AN to be between 50 to $60 \%$, indicating a considerable

61 contribution of genetic factors to $\mathrm{AN}$ disease liability $(9,10)$.

62

63 Both metabolic and psychiatric factors contribute to anorexia nervosa. Epidemiological studies indicate

64 high rates of psychiatric comorbidity, particularly with depression, anxiety disorders, and $O C D(5)$, and

65 many of these disorders share substantial symptomatology and environmental risk factors(11). Evidence

66 is mounting that AN may lie at the extreme of a BMI spectrum, with obesity lying at the opposite end, and

67 that AN may be a disorder of "fundamental metabolic dysregulation"(2). In line with this hypothesis,

68 individuals with AN are able to reach and maintain incredibly low body weight, and often revert to this

69 weight even after re-nourishment treatment, possibly indicating a fundamentally low BMI biological

70 settling point(12,13). Additionally, individuals with AN have been shown to have lower concentrations of

71 leptin, a hormone involved in regulation of body weight and other metabolic processes(13-16).

72 Microbiome studies have revealed abnormal microflora in the gut of AN patients(17), and evidence from

73 many studies have pointed to a possible brain-gut etiology of $\mathrm{AN}(9,18-20)$.

74

75 Genetic studies of AN have provided further evidence of both psychiatric and metabolic etiology. The

76 largest $\mathrm{AN}$ GWAS to date $\left(\mathrm{N}_{\text {Cases }}=16992\right)$ uncovered eight loci associated with $\mathrm{AN}$ risk(9), and determined

77 SNP-based heritability $\left(\mathrm{h}^{2}\right.$ SNP $)$ of $11-17 \%$, similar to other psychiatric disorders, indicating that common

78 variants contribute to polygenic risk of AN. In addition, genetic correlations demonstrate significant 
medRxiv preprint doi: https://doi.org/10.1101/2021.02.12.21250941; this version posted March 13, 2021. The copyright holder for this preprint (which was not certified by peer review) is the author/funder, who has granted medRxiv a license to display the preprint in perpetuity.

It is made available under a CC-BY-NC-ND 4.0 International license .

79 overlap with other psychiatric disorders, including schizophrenia(9,21), $\operatorname{MDD}(9), \operatorname{OCD}(9)$, alcohol use

80 disorder(22) and anxiety disorders(9), as well as physical activity $(9,23)$, indicating shared genetic

81 variation between these traits. Significant negative genetic correlation between AN and anthropometric

82 and metabolic traits, such as $\operatorname{BMI}(9,21,23)$, fat mass $(9,21,23)$, obesity $(9)$, type 2 diabetes(9), insulin

83 resistance $(9,21)$, fasting insulin $(9,21)$ and leptin(9) have also been observed, further indicating metabolic

84 components to AN disease risk. One study of AN polygenic risk scores (PRS) has indicated additional

85 genetic associations of AN risk variants with anthropometric, behavioral, and psychiatric traits(24).

87 Traditional observational genetic studies provide substantial data for factors contributing to risk of a

88 particular disease, but may not capture the genetic factors that are specifically contributing to

89 subthreshold or prodromal disease states. Electronic Health Records (EHR) contain information about an

90 individual's health history such as diagnoses, medications, laboratory tests, vital signs, and family medical

91 history, and can be utilized for scalable disease research. The vast amounts of data from the EHR can be

92 queried to provide an understanding of the clinical spectrum of disease and disease progression across

93 the lifetime of the patient. The initiation of biobanks to collect biological specimens from large numbers of

94 patients within a healthcare system allows us to connect massive amounts of phenotype data from the

95 EHR to genetic data. A phenome-wide association study or PheWAS is an effective method of querying

96 the EHR to look for the associations of a trait of interest with the clinical phenome'(25-27). Previous

97 studies have demonstrated the efficacy of PheWAS methods in determining clinical outcomes associated

98 with genomic disease risk variants, and have replicated associations from GWASs of strictly defined

99 disease traits, including psychiatric disorders(28-30)' Exploring the phenotypic associations with AN

100 genetic architecture has the potential to clarify how some of these GWAS variants functionally contribute

101 to AN disease risk, symptomatology, and clinical presentation.

102

103 Transcriptomic imputation (TI) approaches leverage expression quantitative trait loci (eQTLs) derived

104 from large, well-curated gene expression datasets (for example, the Genotype-Tissue Expression project

105 (GTEx)(31), CommonMind Consortium (CMC)(32), and Depression Genes and Networks (DGN)(33)) in

106 order to derive gene expression predictor models. These models may be applied to predict genetically 
medRxiv preprint doi: https://doi.org/10.1101/2021.02.12.21250941; this version posted March 13, 2021. The copyright holder for this preprint (which was not certified by peer review) is the author/funder, who has granted medRxiv a license to display the preprint in perpetuity.

It is made available under a CC-BY-NC-ND 4.0 International license .

107 regulated gene expression (GReX) in large genotyped cohorts, without the need to collect tissue samples

108 or RNA(19,34-36). Here, we explored the association between AN-associated GReX and the clinical

109 phenome. We performed transcriptomic imputation using S-PrediXcan on the most recent PGC-ED AN

110 GWAS to first find GReX associated with AN, and then tested for clinical associations of these genes with

111 structured EHR-encoded phenotypes using PheWAS. Given the relationship of AN with BMI, we further

112 investigated the effect of BMI on the GReX-phenotype associations by stratifying biobank individuals

113 based on sex- and ancestry-adjusted categories of low, mid, and high BMI. Understanding the clinical

114 consequences of aberrant gene expression across the phenome may clarify the biological mechanisms of

115 clinically relevant AN GWAS risk variants.

116

117

118

119

120

121

122

123

124 
medRxiv preprint doi: https://doi.org/10.1101/2021.02.12.21250941; this version posted March 13, 2021. The copyright holder for this preprint (which was not certified by peer review) is the author/funder, who has granted medRxiv a license to display the preprint in perpetuity.

It is made available under a CC-BY-NC-ND 4.0 International license .

\section{METHODS}

127 AN GENELIST and TRANSCRIPTOMIC IMPUTATION

128 We performed transcriptomic imputation using S-PrediXcan(35) on the largest available summary

129 statistics of Anorexia Nervosa (AN) (16992 AN cases and 55525 controls) downloaded from the

130 Psychiatric Genomics Consortium (PGC) website(9). We tested for association of genetically-regulated

131 gene expression (GReX) using available GTEx, CMC and DGN predictor models(34-36) for a total of 50

132 different tissues with AN case-control status. We established two thresholds for significance; first,

133 correcting for all genes tested within each tissue $\left(\mathrm{p}_{\text {tissue }}\right.$, values shown in Table $\mathbf{S 1}$, and second,

134 correcting for all tissues and genes tested ( $\left.p_{\text {bonferroni }}=3.75 \times 10^{-8}\right)$.

135

\section{Bio $M e^{T M}$}

137 The BioMe ${ }^{T M}$ Biobank at the Icahn School of Medicine at Mount Sinai includes genotype and EHR data

138 from 31704 individuals recruited from the general patient population of the Mount Sinai healthcare

139 system. Individuals were genotyped on the Illumina Global Screening Array (GSA), an array designed for

140 multi-ethnic populations. The Bio $M e^{T M}$ population is very diverse, with the proportion of major ancestral

141 population groups representative of the diversity of New York City and Mount Sinai's patient population:

142 Hispanic (HA, 35\%), European (EA, 34\%), African (AA, 25\%), East Asian (ESA, 3\%), South Asian (SAS,

$1432 \%$ ), and Native American (NA, 0.3\%) (Full BioMe ${ }^{T M}$ demographics are shown in Table 1). Quality control

144 and imputation of the genotyping data for BioMe ${ }^{T M}$ is described in elsewhere(28).

145

146 Ancestry for BioMe ${ }^{T M}$ was initially assigned from self-reported values into six ancestral groupings: African

147 (AA), European (EA), Hispanic (HA), East Asian (ESA), Native American (NA), and O (Other). We plotted

148 the first two principal components from the genotyping to confirm ancestral grouping. For individuals not

149 clearly falling in an ancestral group, and for those designated "Other", we merged genotype information

150 with phase 3 of 1000 Genomes and reran the principal components analysis (PCA) using PLINK $(37,38)$ in

151 order to assign individuals to 1000 Genomes super-populations. From this we were able to assign

152 individuals to one of six ancestral groups: African (AA), European (EA), East Asian (ESA), Hispanic (HA), 
medRxiv preprint doi: https://doi.org/10.1101/2021.02.12.21250941; this version posted March 13, 2021. The copyright holder for this preprint (which was not certified by peer review) is the author/funder, who has granted medRxiv a license to display the preprint in perpetuity.

It is made available under a CC-BY-NC-ND 4.0 International license .

153 Native American (NA), and South Asian (SAS). A total of 119 samples that could not be grouped were

154 removed, leaving 31585 individuals for analysis.

155

156 PheWAS

157 We calculated GReX for all $p_{\text {tissue }}$ significant genes across GTEx(31), DGN(33), and CMC(32,39) tissues

$158(\mathrm{~N}=50)$ in BioMe ${ }^{T M}$ individuals using PrediXcan-2(34,35) software, and performed a phenome-wide

159 association (PheWAS) analysis. Logistic regression between the calculated AN-GReX and phecodes was

160 performed using the PheWAS R package(40), adjusting for age, biological sex, and the first five

161 genotype-derived principal components. PheWAS were run per BioMe ${ }^{T M}$ ancestry cohort of $\left(\mathrm{N}_{\text {Ancestry }}=6\right)$

162 and results meta-analyzed using an inverse-variance based approach in METAL(41). Due to the nature of

163 EHR data, sample sizes can vary greatly depending on the phenotype, which can, in turn, affect our

164 ability to detect associations. We believe our study is sufficiently powered given results from a previous

165 study(42) that used simulations of MAF, penetrance and sample number parameters to estimate power

166 for pheWAS studies.

167

168 Encounter Diagnosis

169 Current diagnoses for each individual were recorded at each visit using the International Classification of

170 Disease (ICD) coding system and recorded as "Encounter Diagnosis". Phecodes were assigned from

171 Encounter Diagnosis information by grouping ICD-9 and ICD-10 diagnostic codes(43). Individuals with at

172 least two counts of a particular diagnostic code were considered "cases", those with zero counts were

173 marked as "controls", and those with only one count were set to missing. After QC, there were a total of

1742178 unique Encounter Diagnosis codes and 1093 unique phecodes in the dataset.

175

176 For both encounter diagnoses and phecodes, we required at least 10 occurrences of each phenotype

177 within each population group for inclusion in the analysis, and an overall effective sample size $\mathrm{N}_{\text {eff }}>$

178100 (Equation 1).

$$
\mathrm{N}_{e f f}=\frac{4}{\left(1 / N_{\text {Cases }}\right)+\left(1 / \mathrm{N}_{\text {Controls }}\right)}
$$


medRxiv preprint doi: https://doi.org/10.1101/2021.02.12.21250941; this version posted March 13, 2021. The copyright holder for this preprint (which was not certified by peer review) is the author/funder, who has granted medRxiv a license to display the preprint in perpetuity.

It is made available under a CC-BY-NC-ND 4.0 International license .

181 Due to the high correlation between Encounter Diagnosis and phecode files, we combined all results from

182 both PheWAS and performed an FDR correction in $R$ to determine overall significant associations with

183 diagnostic phenotypes. Significant associations were set at an FDR-corrected $\mathrm{p}$ threshold of 0.05.

185 BioMe-R Structured Phenotype Database (BRSPD) PheWAS

186 In addition to diagnosis code data, we also had access to other types of EHR-derived data that included

187 information on allergy status, vital signs (weight, height, blood pressure, pulse, pulse oximetry,

188 respirations, and temperature), family history, personal history, medication use, obstetrics and

189 gynecology outcomes (OB/GYN), and other social and behavioral traits. This information derived from the

190 EHR was collected into files under the heading BRSPD or BioMe-R Structured Phenotype Database.

191 Summaries and descriptive statistics of all of the BRSPD phenotypes can be found in Supplementary

192 Methods. For all BRSPD traits, we required at least ten cases in each ancestry group, and a total

$193 \quad \mathrm{~N}_{\text {eff }}>100$ for inclusion in our analysis.

195 Phenotype QC and Analysis for Continuous Traits

196 We plotted the distribution of continuous traits across the cohort, and removed implausible or impossible

197 values (likely due to errors in entry; for example, height listed as 1745 inches). Continuous traits were

198 then analyzed as follows:

199 1. Height $(\mathrm{cm})$ : mean measure per individual.

200 2. Weight (kg): (i) highest recorded weight, (ii) lowest recorded weight, (iii) weight change over time.

201 Weight change over time was calculated by taking the difference between the highest and lowest

202 recorded weights, divided by the number of years between those two measures.

203 3. Pain scores were self-reported on a 1 to 10 scale and assessed for 25 different body locations.

204 First, we tested pain score regardless of location, using three measures: (i) highest ever pain

205 score, (ii) mean pain score, (iii) total pain score (sum), to encompass both acute and chronic pain

206 conditions. We then repeated this analysis to each reported pain location, with the same three

207 measures. 
medRxiv preprint doi: https://doi.org/10.1101/2021.02.12.21250941; this version posted March 13, 2021. The copyright holder for this preprint (which was not certified by peer review) is the author/funder, who has granted medRxiv a license to display the preprint in perpetuity.

It is made available under a CC-BY-NC-ND 4.0 International license .

4. Measures of alcohol, tobacco, and illicit drug use were categorized as follows: alcohol- ounces

(oz) per day; tobacco- (i) packs per day and (ii) years used; illicit drug use- frequency of use.

5. Vital signs (blood pressure, pulse, pulse oximetry, respiration, temperature (Celsius)) were analyzed using (i) highest ever value, (ii) lowest ever value, (iii) mean, (iv) variance per individual.

\section{Categorical Traits}

214 Categorical traits were converted to binary TRUE/FALSE values (phenotypes included are shown in

215 Supplemental Information). For allergy and medication phenotypes, we collapsed and combined data

216 on equivalent root components and/or active ingredients (e.g., allergies for the antibiotic Vancomycin

217 were coded as "VANCOMYCIN", "VANCOMYCIN HCL", "VANCOMYCIN IN D5W", "VANCOMYCIN IN

218 0.9\% SODIUM CL", "VANCOMYCIN IN DEXTROSE ISO-OSM", and "VANCOMYCIN (BULK)"), removed

219 extraneous symbols and corrected typing errors. A full account of QC steps is documented in the

220 Supplementary Methods.

\section{STRATIFICATION BY BMI}

223 Given the nature of AN symptomology and association with weight phenotypes, we tested whether AN-

224 GReX associations varied based on BMI. We stratified BioMe ${ }^{T M}$ individuals into three main BMI

225 categories, defined based on ancestry- and sex-specific BMI distributions within our data (Figures S1

226 and S2; Tables S2 and S3). BMI values used for these analyses were measured at intake into BioMe ${ }^{\mathrm{TM}}$.

227 We categorized individuals with BMI within the $1^{\text {st }}$ quartile as "Low" BMI; those above the $3^{\text {rd }}$ quartile as

228 "High" BMI, and those falling between the $1^{\text {st }}$ and $3^{\text {rd }}$ quartiles as "Mid" BMI (Figure S1). We then

229 repeated our analysis in these three groups for all significant associations from our full analysis. 
medRxiv preprint doi: https://doi.org/10.1101/2021.02.12.21250941; this version posted March 13, 2021. The copyright holder for this preprint (which was not certified by peer review) is the author/funder, who has granted medRxiv a license to display the preprint in perpetuity.

It is made available under a CC-BY-NC-ND 4.0 International license .

\section{Testing for hidden case contamination}

231 It is possible that some of the clinical associations within our study stem from undiagnosed ED- and AN-

232 cases, rather than a direct effect of gene expression on phenomic expression. We term this "diagnostic

233 contamination". To test whether this effect may drive the associations we observe, we simulated the

234 effects of diagnostic contamination occurring at rate $p$ within our biobank sample, with effect $\beta$ on GReX.

236 Full derivations and simulations are shown in our Supplementary Material; briefly, we derive the

237 expression among controls, and cases contaminated at rate $p$; the difference in expression between the

238 two groups; the expected variance among cases, and pooled across all samples, and the expected

239 statistical significance (T-score, and p-value). Next, we simulated gene expression distributions for (i)

2401000 cases and 1000 controls; (ii) 1000 cases and 10000 controls; (iii) 1000 cases and 30000 controls;

241 each for a range of $p(0.1 \%, 0.5 \%, 1 \%, 2 \%, 5 \%, 10 \%, 20 \%, 30 \%, 40 \%, 50 \%)$ and $\beta(1 / 10,1 / 5,1 / 4,1 / 3,1 / 2$,

$2421,2,3,4,5,10)$ values. We repeated our simulations 10000 times at each case-control proportion- $p$ - $\beta$

243 combination, and demonstrated that our formulae accurately estimate the desired values (Figure S3).

245 Next, in order to test whether diagnostic contamination may account for the associations observed within

246 our PheWAS, we calculated the expected impact of diagnostic contamination for two genes (NCKIPSD-

247 Aorta; SEMA3F-Spinal Cord) with the largest effect sizes $\beta$ observed in our S-PrediXcan analysis, under 248 two scenarios:

249 1. Diagnostic contamination occurs among our cases only, assuming the normal population rate for AN: $0.9 \%$ among women; $0.3 \%$ among men.

2. Contamination occurs at significantly higher levels than might be expected in the population

254 For each scenario, we repeated our calculation using 500 and 1000 cases, matched with 1000, 5000, and 25530000 controls. 
medRxiv preprint doi: https://doi.org/10.1101/2021.02.12.21250941; this version posted March 13, 2021. The copyright holder for this preprint (which was not certified by peer review) is the author/funder, who has granted medRxiv a license to display the preprint in perpetuity.

It is made available under a CC-BY-NC-ND 4.0 International license .

\section{S-PrediXcan identifies gene-tissue associations with AN}

260 We applied S-PrediXcan to PGC-AN GWAS summary statistics, and identified 47 genes across 12 loci,

261 two loci on chromosomes 2 and 3 that reached experiment-wide significance $\left(p<3.75 \times 10^{-8}\right.$; Figure 1,

262 Table 2, Table S4), and another 10 loci that reached tissue-specific significance (Each tissue type has its

263 own p value threshold of significance; Figure 1, Table 2, Table S4). These 12 loci encompass 218 gene-

264 tissue associations (which may include the same gene associated across multiple tissues). The most

265 significant peak on chromosome 3 includes 29 genes with significant associations with AN; this region of

266 the genome overlaps with a GWAS peak for inflammatory bowel disease (IBD)(44), Crohn's disease, and

267 ulcerative colitis. Many of the AN-associated genes within this peak have been found to be associated

268 with IBD. Genes included in our AN GReX gene set have been previously associated not only with IBD,

269 but with other psychiatric traits such as schizophrenia (ARNTL, CLIC1), depression and/or depressive

270 symptoms (C3orf62, CCDC36, CLIC1, DAG1, GPX1, MST1R), autism (CLIC1), and substance use

271 (RBM5, RBM6), as well as anthropometric measures such as BMI, waist-hip ratio, and lean body mass

272 (Table S5). Of these genes, CLIC1 lies within the major histocompatibility complex (MHC), a large region

273 on chromosome 6 that includes genes that code for components of the adaptive immune system (Tibial

274 nerve-CLIC1, $\mathrm{p}=1.47 \times 10^{-6}$ ). To our knowledge, this is the first genetic association for AN within the MHC

275 region.

\section{AN-GREX is associated with anthropometric measures}

278 We tested whether GReX of AN-associated genes was associated with anthropometric phenotypes in our

279 BioMe ${ }^{\mathrm{TM}}$ biobank (Table 3). In the overall cohort, upregulation of MHC-gene CLIC1 was associated with

280 lowest recorded weight (Spleen-CLIC1, $\mathrm{p}=6.63 \times 10^{-4}$; Breast Mammary tissue-CLIC1, $\mathrm{p}=4.18 \times 10^{-4}$ ) and

281 mean height (Subcutaneous Adipose-CLIC1, $\mathrm{p}=1.39 \times 10^{-5}$; Table S6). Downregulation of multiple genes,

282 ARIH2, NCKIPSD, NDUFAF3, NICN1, P4HTM, RNF123, SLC26A10, was associated with decreased

283 measures of weight change over time in the overall cohort $\left(p<9.86 \times 10^{-4}\right)$ (Table 3, Figure S4).

284 Upregulation of WDR6 was associated with increased measures of weight change over time $(p<9.81 \times 10$ 
medRxiv preprint doi: https://doi.org/10.1101/2021.02.12.21250941; this version posted March 13, 2021. The copyright holder for this preprint (which was not certified by peer review) is the author/funder, who has granted medRxiv a license to display the preprint in perpetuity.

It is made available under a CC-BY-NC-ND 4.0 International license .

$285^{4}$ )(Table 3, Figure S4). CTNNB1, GPR75 and LINC00324 GReX was associated with mean height in $286 \operatorname{BioMe}^{\mathrm{TM}}\left(\mathrm{p}<6.51 \times 10^{-4}\right)($ Table S6).

\section{Patient BMI mediates AN-GREX-PheWAS associations}

289 Given the relationship of AN with BMI, we performed a secondary analysis to assess the effect of BMI on

290 the association between AN-GReX and anthropometric phenotypes. Specifically we wanted to look at

291 whether our AN-GReX-phenotype associations in individuals of High and Low BMI were still present

292 when BMI was within a normal range. We split the BioMe ${ }^{\mathrm{TM}}$ cohort into three groups: High, Mid, and Low

293 BMI (adjusted for ancestry and sex; see Methods and Supplementary Information for more details),

294 and re-ran our PheWAS within these groups. Indeed, our AN-GReX anthropometry associations (with

295 highest recorded weight, lowest recorded weight, and weight change over time) varied according to the

296 BMI group tested (Figure 2, Table 3). The association between CLIC1-GReX and highest and lowest

297 recorded weight measures was strongest in individuals of High BMI compared with the other BMI groups

298 (Figure 2, Table 3). Likewise, for multiple genes, associations between AN-GReX and weight change

299 over time differed markedly in the High BMI group (Table 3, Figure S5).

AN-GREX is associated with autoimmune and autoinflammatory diseases

302 At a false discovery rate (FDR) $p<0.05$, we found 17 FDR-significant gene-tissue associations with four

303 Phecode- and Encounter Diagnosis phenotypes: type I diabetes, celiac disease, peptic ulcer, and

304 unspecified immunodeficiency (Figure 3). Upregulation of CLIC1 in spleen was associated with two

305 autoimmune/autoinflammatory phenotypes in the overall $\mathrm{BioMe} \mathrm{TM}^{\mathrm{TM}}$ cohort: celiac disease and type I

306 diabetes ( $\mathrm{p}=1.30 \times 10^{-11}, \mathrm{p}=5.08 \times 10^{-20}$, respectively) (Tables S7 and S8). Downregulation of SLC26A6

307 was associated with the phenotype "peptic ulcer, site unspecified" in the overall cohort (Liver-SLC26A6,

$308 \mathrm{p}=8.38 \times 10^{-8}$; Skeletal muscle-SLC26A6, $\mathrm{p}=1.71 \times 10^{-7}$; Thyroid-SLC26A6, $\mathrm{p}=7.16 \times 10^{-8}$ ).

309 Downregulation of PFKFB4 was associated with ICD10 code D84.9, "immunodeficiency, unspecified"

310 (Skin not sun exposed-PFKFB4, $\mathrm{p}=1.34 \times 10^{-7}$ ). We stratified our cohort by BMI (see Methods) to assess

311 whether BMI was modifying the association of AN-GReX with Encounter Diagnosis and phecodes. We

312 saw significant associations of AN-GReX phecodes within our Mid BMI group; however, when plotted 
medRxiv preprint doi: https://doi.org/10.1101/2021.02.12.21250941; this version posted March 13, 2021. The copyright holder for this preprint (which was not certified by peer review) is the author/funder, who has granted medRxiv a license to display the preprint in perpetuity.

It is made available under a CC-BY-NC-ND 4.0 International license .

313 across the BMI groups, there was no notable difference in the magnitude and direction of effect of AN-

314 GReX on either Encounter Diagnosis or phecodes across the BMI groups (Figures S6 and S7). Within

315 individuals with Mid BMI, upregulation of CLIC1 was similarly associated with type 1 diabetes (Mid-

316 Subcutaneous adipose, Mid-Breast Mammary tissue, Mid-Spleen-CLIC1, $\mathrm{p}<1.96 \times 10^{-8}$ ).

318 AN-GREX is associated with tobacco, alcohol, and illicit drug use

319 Multiple AN genes were associated with both categorical and continuous measures of tobacco use (Table 320 S9, Figure S8). APEH, CCDC36, DALRD3, GPX1, LINC00324, NICN1, and P4HTM were associated

321 with years used/smoked of tobacco in the overall BioMe ${ }^{\mathrm{TM}}$ cohort $\left(\mathrm{p}<4.97 \times 10^{-4}\right.$, Table S9) and

322 upregulation of MGMT was associated with being a smoker (Heart Atrial Appendage-MGMT, $\mathrm{p}=8.87 \times 10^{-}$

$323{ }^{5}$; Putamen basal ganglia-MGMT, $\mathrm{p}=1.09 \times 10^{-4}$ ). Again, we note mediating effects of patient BMI category

324 on the association between AN-GReX and smoking phenotypes. Among the Mid and High BMI groups,

325 different genes were associated with both continuous and categorical measures of tobacco use (Table

326 S9, Figure S8), including years of tobacco use, tobacco cigarette packs per day, and smoking every day.

327 In addition to tobacco use measures, we see an association between AN genes and tobacco use related

328 ICD codes. Downregulation of LINC00324 in Low BMI individuals was associated with ICD10 diagnosis

329 code F17.210 "Nicotine dependence, cigarettes, uncomplicated" (Low-Cells EBV-tranformed-LINC00324, $\left.330 \mathrm{p}=3.03 \times 10^{-5}\right)$.

332 Downregulation of MGMT was associated with decreased alcohol use (ounces per week) in individuals in 333 the Mid-BMI group ( $\mathrm{p}<9.75 \times 10^{-4}$; Figure S8). In individuals of Low BMI, downregulation of GPR75 and 334 GPX1, and upregulation of NICN1 were associated with decreased and increased continuous measures 335 of illicit drug use frequency respectively (Liver-GPR75, $p=3.34 \times 10^{-4}$; Nucleus accumbens-GPX1, $p=2.04$ $336 \times 10^{-4}$; Testis-NICN1, $\mathrm{p}=3.34 \times 10^{-4}$; Figure S8).

339 We tested for association between AN-GReX and three sets of pain score measures: (1) pain location, (2) 340 pain score overall, (3) pain score by body location. AN-GReX was associated with multiple measures of 
medRxiv preprint doi: https://doi.org/10.1101/2021.02.12.21250941; this version posted March 13, 2021. The copyright holder for this preprint (which was not certified by peer review) is the author/funder, who has granted medRxiv a license to display the preprint in perpetuity.

It is made available under a CC-BY-NC-ND 4.0 International license .

341 pain score measurement and location across all BMI groups (Table S10). Most significantly, upregulation

342 of TNFSF12 was associated with total knee pain score (sum) in individuals with High BMI (High-Brain

343 Substantia nigra-TNFSF12, $\mathrm{p}=1.50 \times 10^{-3211}$ ). Downregulation of TNFSF12 was associated with total

344 abdomen pain score (sum) in individuals with Low BMI (Low-Brain Substantia nigra-TNFSF12, $\mathrm{p}=3.93 \mathrm{x}$

$\left.34510^{-58}\right)($ Table S10).

346

347 When looking at pain location irrespective of pain score, upregulation of TUSC2 in the overall cohort is 348 associated with presence of knee pain (Pancreas-TUSC2, $\mathrm{p}=7.62 \times 10^{-6}$ ) and downregulation of CTNNB1

349 in Mid BMI individuals is associated with the presence of left leg pain (Mid-Stomach-CTNNB1, $\mathrm{p}=1.93 \mathrm{x}$

$35010^{-5}$ ) (Figure 4, Table S10). Repeating this analysis according to BMI category reveals a very large

351 number of associations specific to the Low BMI category (Figure 4, Table S10); in particular, we note 129

352 gene-tissue associations with presence of foot pain, nine of which pass phenotype-wide significance,

353 which may indicate a propensity to excess exercise, or exercise-related injuries among these individuals.

355 Upregulation of CLIC1 is associated with glucagon medication

356 AN-GReX PheWAS with medication phenotypes was associated with glucagon, a hormone used to treat

357 severe hypoglycemia, in the overall BioMe ${ }^{\mathrm{TM}}$ cohort. Upregulation of CLIC1 was associated with glucagon

358 in the overall cohort (Spleen-CLIC1, $\mathrm{p}=4.20 \times 10^{-9}$ ) and also in individuals with Mid BMI (Mid-Spleen-

359 CLIC1, $\left.\mathrm{p}=2.09 \times 10^{-6}\right)$ (Figure S9, Table S11).

360

\section{Identifying potential case contamination effects}

362 Our BioMe ${ }^{\mathrm{TM}}$ patients have not all been explicitly assessed for eating disorders (ED), and information

363 regarding ED diagnoses and assessments earlier in life may be omitted from the records due to

364 incomplete clinical history assessments. Therefore, it is possible that diagnostic contamination within

365 some of our sample is responsible for the associations observed within our data. In order to test this, we

366 performed a simple experiment. 
medRxiv preprint doi: https://doi.org/10.1101/2021.02.12.21250941; this version posted March 13, 2021. The copyright holder for this preprint (which was not certified by peer review) is the author/funder, who has granted medRxiv a license to display the preprint in perpetuity.

It is made available under a CC-BY-NC-ND 4.0 International license .

368 For this simple experiment, we assume that diagnostic contamination occurs among true cases only, at

369 prevalence $p$. In this case, we expect gene expression among those individuals to be up- or down-

370 regulated by effect size beta; consequently, we expect a gene expression difference between cases and

371 controls proportional to the prevalence of the contamination within the sample $(p)$ and the effect size

372 (beta); (Supplementary information). We tested whether such contamination may drive the associations

373 observed in our study, assuming the following different contamination scenarios (Table S12), for two

374 genes with large S-PrediXcan effect sizes: (i) that contamination occurs among cases, assuming the

375 highest common estimate for AN prevalence ( $0.9 \%$ among women, $0.3 \%$ among men); (ii) that

376 contamination occurs within our biobank, assuming the highest common estimate for AN prevalence

$377(0.6 \%, 190$ cases $)$, and that all of these samples fall into our 'case' category.

378

379 Our model indicates that diagnostic contamination among cases is unlikely to result in significant

380 PheWAS associations in our data. Contamination occurring at population ED prevalence (0.6\%) did not

381 result in significant associations for any of the case-control scenarios in our model (Table S12); nor did

382 contamination at $1.2 \%$ or $3 \%$. Assuming $6 \%$ contamination resulted in potentially significant associations

383 (estimated $\mathrm{p}<2.8 \times 10^{-8}$; see Methods and Supplementary Methods for more detail). 
medRxiv preprint doi: https://doi.org/10.1101/2021.02.12.21250941; this version posted March 13, 2021. The copyright holder for this preprint (which was not certified by peer review) is the author/funder, who has granted medRxiv a license to display the preprint in perpetuity.

It is made available under a CC-BY-NC-ND 4.0 International license .

DISCUSSION

387 AN-associated genes are enriched for associations with psychiatric, autoimmune, and

388 anthropometric phenotypes.

389 Our S-PrediXcan gene results illustrate the contribution of genes associated with metabolic,

390 anthropometric, autoimmune, and psychiatric phenotypes to AN, and 53\% of our genes (25/47) overlap

391 with those from a previous prediXcan analysis of AN cohorts(9). 24/47 AN genes (51\%) had variants that

392 were previously associated with some autoimmune disorder in GWAS studies (Table S5). The

393 experiment-wide significant loci on chromosome 3 overlaps with a known GWAS peak for inflammatory

394 bowel disease(44) (IBD), and many of the genes within that peak that we found associated with AN were

395 also associated with disorders under the IBD umbrella such as Crohn's and ulcerative colitis (Table S5),

396 demonstrating further shared genetic architecture of AN with autoimmune and autoinflammatory

397 disease $(7,8,45,46)$. Earlier AN GWAS studies have found AN risk loci that overlap with loci implicated in

398 autoimmune disease(47), but the association of CLIC1 gene expression in tibial nerve that we have found

399 is the first known association of AN with the MHC locus, a region that has been associated with many

400 other psychiatric disorders $(48,49)$ as well as autoimmune disorders. In particular, CLIC1 has previously

401 been identified as associated with schizophrenia(50), autism(50), major depressive disorder(51), post-

402 traumatic stress disorder(52), neuroticism(53) and depressive phenotypes(53). Importantly, CLIC1

403 variants have also been associated with complement component C4 and C3 protein levels in the

404 blood(54). $C 4$ is a gene with two isotypes, $C 4 A$ and $C 4 B$, that, through various structural allelic

405 combinations, give rise to complement component 4, which, along with complement component 3 (C3), is

406 part of the complement cascade of proteins(55). Previous research has shown that the complement

407 cascade is involved in not only immunological functions of pathogen clearance (e.g., tagging pathogens

408 for destruction), but also in synaptic pruning and neuronal connectivity(56). The $C 4 A$ isotype has been

409 associated with schizophrenia risk(55), and both $C 4 A$ and $C 4 B$ genes had subthreshold associations with

410 AN in our dataset. 
medRxiv preprint doi: https://doi.org/10.1101/2021.02.12.21250941; this version posted March 13, 2021. The copyright holder for this preprint (which was not certified by peer review) is the author/funder, who has granted medRxiv a license to display the preprint in perpetuity.

It is made available under a CC-BY-NC-ND 4.0 International license .

412 CLIC1 (Chloride Intracellular 1) encodes a chloride ion channel protein involved in many necessary

413 cellular functions including the regulation of cell membrane potential, and the proliferation and

414 differentiation of cells(57), including a role in axonal outgrowth of neurons ${ }^{51}$. In addition to neurons,

415 CLIC1 has been found to be expressed in many different tissue types(59), and in particular, CLIC1

416 protein has been found to accumulate in peripheral blood mononuclear cells (PBMCs) when the central

417 nervous system is in a state of chronic inflammation(58), and increased CLIC1 expression has been

418 shown to occur in microglia stimulated by the presence of $\beta$-amyloid in vitro(60,61). Therefore, CLIC1

419 may potentially act as a biomarker for neurodegenerative disorders such as Alzheimer's disease, and

420 downregulation of CLIC1 has been shown to have a neuroprotective effect in the presence of $\beta$-amyloid

421 proteins(58,60-62). Variants in CLIC1 may contribute to risk of multiple psychiatric disorders and

422 behaviors, such as schizophrenia, MDD and PTSD, as well as many autoimmune and immune-related

423 phenotypes such as asthma and systemic lupus erythematosus(50-53)'(63) (Table S5). Many studies

424 have posed the role of inflammation in the development of psychiatric disorders, and in the etiology of

$425 \quad \mathrm{AN}(7,8,45,46,64)$.

426

427 Multiple genes (8/47 or $17 \%$ ) in our results were associated with regular gym attendance (Table S5), or 428 measures of physical activity. Excessive and compulsive exercise is a behavior often seen in individuals 429 with $\mathrm{AN}(65,66)$, and evidence is suggestive that hyperactivity increases risk of chronic $\mathrm{AN}(67,68)$.

430 Likewise, genetic studies have shown a strong genetic correlation between AN and physical activity

$431\left(r_{g}=0.17\right)(9,23,69)$. These genes may reflect a genetic liability to compulsive behaviors of physical activity.

432 Our pain location results point to possible symptoms of excessive activity, with the strong association of

433 AN-GReX with foot pain in Low BMI individuals. Given the known association of AN disease with low

434 bone mineral density (BMD) and propensity for bone fracture(70), our results may reflect the result of

435 genes associated with compulsive exercise and BMD contributing to increased osteoarticular pain. We

436 also see multiple genes that have been previously associated with decreased sleep and insomnia

437 phenotypes (including a core circadian clock gene $A R N T L$ ), which have previously been implicated in a

438 range of psychiatric disorders(71-82), including eating disorders(83), as well as in satiety and

439 hunger(84,85). 
medRxiv preprint doi: https://doi.org/10.1101/2021.02.12.21250941; this version posted March 13, 2021. The copyright holder for this preprint (which was not certified by peer review) is the author/funder, who has granted medRxiv a license to display the preprint in perpetuity.

It is made available under a CC-BY-NC-ND 4.0 International license .

441 In a patient population, expression of AN genes is associated with psychiatric, metabolic, and

442 autoimmune phenotypes

443 Unlike GWAS, which include carefully constructed case-control cohorts, PheWAS encompass all

444 individuals within a given healthcare system, including patients with subthreshold or partial presentations

445 of a disorder, or individuals with commonly comorbid or co-diagnosed conditions. Importantly, because

446 individuals enrolled in the biobank are not ascertained for any specific disorder, they likely represent a

447 comprehensive clinical picture of the comorbidities and symptomatology associated with AN gene

448 expression. Examining the consequences of aberrant predicted gene expression among these patients

449 (i.e., testing for GReX-associations) may reveal clinical and biological consequences of these genes; for

450 example, studying whether $\mathrm{AN}$-associated genes have anthropometric and metabolic consequences

451 among adults with no evidence for previous AN- or ED-diagnoses may disentangle whether certain

452 endophenotypes present as a cause, or consequence of AN. For example, it has been postulated that

453 behaviors of food avoidance and restriction may arise due to gastrointestinal complaints and distress that

454 provoke these behaviors and precede development of $\mathrm{AN}(86)$. Likewise, autoimmune disorders of the

455 gastrointestinal tract, such as celiac disease and Crohn's disease, show a bidirectional relationship with

456 AN, with previous diagnosis of a Gl-associated autoimmune disorders increasing the risk of AN and vice

457 versa(8). Our pheWAS results of AN-GReX associations with gastrointestinal symptoms such as

458 abdominal pain, ascites, and peptic ulcer, as well as Gl-related autoimmune disorders like celiac disease,

459 suggest AN-GReX may contribute directly to these diseases and phenotypes, and that food aversive

460 behaviors and gastric distress may be genetically regulated in these individuals, rather than occurring as

461 a consequence of AN. While these associations could be the consequence of undiagnosed AN

462 individuals in our biobank, they more likely reflect real biological associations of expression of those

463 particular genes with the phenotype.

464

465 Our results further confirm the contribution of metabolic factors to AN etiology as we see a very robust

466 association of AN-GReX with type 1 diabetes, and our top findings for AN-GReX with medication

467 prescriptions include the hyperglycemic hormone glucagon and various forms of insulin. The association 
medRxiv preprint doi: https://doi.org/10.1101/2021.02.12.21250941; this version posted March 13, 2021. The copyright holder for this preprint (which was not certified by peer review) is the author/funder, who has granted medRxiv a license to display the preprint in perpetuity.

It is made available under a CC-BY-NC-ND 4.0 International license .

468 of AN with metabolic traits and abnormalities has been fairly well established. The Anorexia Nervosa

469 Genetics Initiative reported significant negative genetic correlation between AN and a number of

470 metabolic traits including insulin resistance $\left(r_{g}=-0.29\right)$, fasting insulin $\left(r_{g}=-0.24\right)$, leptin $\left(r_{g}=-0.26\right)$ and type

4712 diabetes $\left(r_{g}=-0.22\right)$, and a strong positive genetic correlation with HDL cholesterol $\left(r_{g}=0.21\right)(9)$.

472 Additional studies have shown associations of AN with fasting insulin(87) and insulin sensitivity(88).

473 Notably, our results point to a similar role of aberrant glycemic regulation in the etiology of AN. Future

474 analyses including EHR-derived lab results (LabWAS) studies may further elucidate AN genes associated

475 with abnormal metabolic regulation and clinical features.

476

477 BMI modification of AN-GReX on clinical outcomes

478 We stratified our pheWAS analyses by BMI in order to observe whether the effects of predicted AN gene

479 expression on clinical outcomes were modified by BMI status, and whether this modification had a

480 significant impact on clinical phenotypes. Specifically, are the AN-GReX-phenotype associations that we

481 see in individuals of High and Low BMI still present when BMI is within the normal "healthy" range?

482 Understanding how BMI is influencing the association of AN-GReX with the clinical phenome might give

483 us further insight into the biological pathways leading to those outcomes and the conferral of AN disease

484 risk. Additionally, we want to understand how BMI could be interacting with AN genetic risk to influence

485 clinical outcomes. We know from our S-PrediXcan analyses and previous GWAS that many genes found

486 to be associated with AN have variants that have been associated with BMI and other anthropometric

487 traits (Table S5). 20/47 AN-genes (42.6\%) had evidence from previous GWAS of association with

488 anthropometric measures such as BMI, body fat distribution, waist-to-hip ratio, fat-free mass, obesity, and

489 hip circumference. BMI polygenic risk scores (PRS) have been shown to be associated with disordered

490 eating, with high BMI PRS negatively associated with thin ideal internalization and external eating, where

491 individuals tend to eat in response to external cues of the sight or smell of food $(89,90)$.

492

493 We postulate that the modification of AN-GReX-weight associations by BMI could be due to actual

494 biological differences in the regulation of AN gene expression and downstream processes in the presence

495 of different measures of BMI. CLIC1 is involved in pathways of inflammation, and individuals with a higher 
medRxiv preprint doi: https://doi.org/10.1101/2021.02.12.21250941; this version posted March 13, 2021. The copyright holder for this preprint (which was not certified by peer review) is the author/funder, who has granted medRxiv a license to display the preprint in perpetuity.

It is made available under a CC-BY-NC-ND 4.0 International license .

496 BMI have been shown to have increased systemic inflammation(91), especially in adipose tissues, so it is

497 possible that the modification effect by BMI on the effect of CLIC1-GReX on weight measures is

498 happening via a tissue-specific inflammatory process. If we view AN and obesity as metabolic disorders

499 on opposite ends of the spectrum, then perhaps the interaction of BMI with risk for either disorder may

500 lead to differences in metabolic regulation resulting in higher weight phenotypes for those with increased

501 obesity risk, and lower weight phenotypes in those with higher AN risk.

502

503 Although the hypothesis-free, phenome-wide design of our study allows for powerful detection of clinical

504 and biological consequences of AN risk genes, the same design also bears some notable limitations and

505 caveats. One key caveat to our results is the lack of diagnostic detail and insights available for the

506 patients in our study. EHR analyses leverage large, existing data sets to rapidly amass cohorts for

507 analysis, and to yield insights into whole phenome consequences of genotype and GReX associations;

508 however, the scale and scope of these studies precludes deep phenotyping or performing clinical

509 interviews. This lack of diagnostic precision may arise from a number of factors.

510

511 First, we make use of ICD codes within the medical record in order to infer diagnoses; since these are

512 primarily used by clinicians for billing purposes, they likely provide an imperfect proxy for true disease

513 state. In order to mitigate spurious results stemming from imperfectly assigned codes, we established

514 criteria for inclusion of diagnoses in our analyses: First, diagnosis codes with fewer than 10 counts in the

515 biobank were removed. Second, we only included diagnoses in our pheWAS with at least 10 counts of a

516 code in the ancestral population (i.e., ancestral groups with fewer than 10 case counts were not included

517 in the analysis for that diagnosis), and with a total effective sample size after meta-analysis that was

518 greater than 100. Lastly, within each pheWAS, individuals had to have two or more counts of a diagnosis

519 code to count as a "case", whereas individuals with only one count of a diagnosis code were set to

520 "missing" and not included in the analysis.

522 Second, it is possible that our patients regularly receive treatment at multiple different hospital systems;

523 as such, we may be capturing only partial data for each of our patients. In order to mitigate this, we 
medRxiv preprint doi: https://doi.org/10.1101/2021.02.12.21250941; this version posted March 13, 2021. The copyright holder for this preprint (which was not certified by peer review) is the author/funder, who has granted medRxiv a license to display the preprint in perpetuity.

It is made available under a CC-BY-NC-ND 4.0 International license .

524 restricted our analysis to patients with multiple data points within our EHR. Future analyses that seek to

525 harmonize or meta-analyze patient data across EHR (e.g., NYC-CDRN, PsycheMERGE) are ongoing,

526 and will be vital to disentangling this effect further.

528 Importantly, our patients have not all been explicitly assessed for EDs, and information regarding ED

529 diagnoses and assessments earlier in life may be omitted from the records due to incomplete clinical

530 history assessments. Therefore, it is possible that case-contamination within some of our sample is

531 responsible for the associations observed within our data. In order to address this, we performed a simple

532 experiment to simulate the effect sizes expected if undiagnosed AN contamination drives our result. We

533 estimated the expected association statistics observed due to two possible levels of contamination among

534 PheWAS cases; i, that $0.06 \%$ of PheWAS-trait cases are missing a true AN diagnosis- i.e., the proportion

535 of individuals we expect to receive an AN diagnosis based on standard prevalence estimates; ii, that

$5361.2 \%, 3 \%$ and $6 \%$ of individuals in BioMe are missing an AN diagnosis (i.e., double, five times, and ten

537 times the expected population rate), and that all of these individuals fall within our PheWAS trait case

538 group, and applied this model for two genes with large S-PrediXcan effect sizes (NCKIPSD-Aorta;

539 SEMA3F-Spinal Cord). Our model indicates that diagnostic contamination at $0.06 \%, 1.2 \%$ or $3 \%$ is

540 insufficient to account for the effect sizes observed within our PheWAS analysis. Moreover, since these

541 genes are selected due to their large S-PrediXcan effect sizes, we expect that the contamination effects

542 observed for these two genes will be greater than any others in our study; as such, we do not believe that

543 our findings are attributable to hidden case contamination. Contamination at $6 \%$ resulted in significant

544 differences; however, since this estimate represents a >five-fold increase in expected numbers of AN

545 within a population, we do not expect that this level of contamination occurs in our sample.

547 Our results demonstrate that there are real clinical consequences to differences in AN gene expression.

548 Characterization of the phenotypic consequences of $\mathrm{AN}$ gene expression in a clinical setting can give us

549 more insight into the biological mechanisms underlying AN and, consequently, how to diagnose and treat

550 the disorder. By understanding the associations of AN gene expression with symptomatology, prodromal

551 or subthreshold disease states, we may gain insights into the biology of the disease, and perhaps identify 
medRxiv preprint doi: https://doi.org/10.1101/2021.02.12.21250941; this version posted March 13, 2021. The copyright holder for this preprint (which was not certified by peer review) is the author/funder, who has granted medRxiv a license to display the preprint in perpetuity. It is made available under a CC-BY-NC-ND 4.0 International license.

552 therapeutic targets and opportunities for clinical interventions. For example, if gastrointestinal complaints

553 are truly the consequence of aberrant AN gene expression, and contribute to disordered eating due to

554 gastrointestinal distress, treatment of those symptoms may help alleviate other AN symptoms or prevent

555 development of later $\mathrm{AN}(92,93)$. An understanding of the clinical consequences of $\mathrm{AN}$ gene expression

556 can further augment the definition of AN, and could allow clinicians to more broadly identify individuals at

557 greater risk of $\mathrm{AN}$, or those who present with symptom constellations that do not yet meet the established 558 diagnostic threshold. 
medRxiv preprint doi: https://doi.org/10.1101/2021.02.12.21250941; this version posted March 13, 2021. The copyright holder for this preprint (which was not certified by peer review) is the author/funder, who has granted medRxiv a license to display the preprint in perpetuity.

It is made available under a CC-BY-NC-ND 4.0 International license .

\section{Acknowledgements}

560 We are deeply grateful for the mentorship of Pamela Sklar, whose guidance and wisdom we miss daily.

561 We strive to continue her legacy of thoughtful, innovative, and collaborative science.

562

$563 \mathrm{JJ}$ and LMH were supported by funding from the Klarman Family Foundation (2019 Eating Disorders

564 Research Grants Program) and the NIMH (R01MH118278). CMB is supported by NIMH (R01MH120170;

565 R01MH119084; R01MH118278; U01 MH109528); Brain and Behavior Research Foundation

566 Distinguished Investigator Grant; Swedish Research Council (Vetenskapsrådet, award: 538-2013-8864);

567 Lundbeck Foundation (Grant no. R276-2018-4581).

568

569 This work was supported in part through the resources and staff expertise provided by the Charles

570 Bronfman Institute for Personalized Medicine and The Bio $\mathrm{Me}^{\mathrm{TM}}$ Biobank Program at the Icahn School of

571 Medicine at Mount Sinai.

572

573 Research reported in this paper was supported by the Office of Research Infrastructure of the National

574 Institutes of Health under award numbers S100D018522 and S100D026880. The content is solely the

575 responsibility of the authors and does not necessarily represent the official views of the National Institutes

576 of Health.

577

578 Competing Interests

579 CMB reports: Shire (grant recipient, Scientific Advisory Board member); Idorsia (consultant);

580 Pearson (author, royalty recipient). ML declares that over the past 36 months, he has received lecture

581 honoraria from Lundbeck pharmaceutical (No other equity ownership, profit-sharing agreements,

582 royalties, or patent). The remaining authors declare no competing interests.

583

584 
medRxiv preprint doi: https://doi.org/10.1101/2021.02.12.21250941; this version posted March 13, 2021. The copyright holder for this preprint (which was not certified by peer review) is the author/funder, who has granted medRxiv a license to display the preprint in perpetuity. It is made available under a CC-BY-NC-ND 4.0 International license .

REFERENCES:

1. Zipfel S, Giel KE, Bulik CM, Hay P, Schmidt U. Anorexia nervosa: aetiology, assessment, and treatment. Lancet Psychiatry. 2015 Dec;2(12):1099-111.

2. Bulik CM, Flatt R, Abbaspour A, Carroll I. Reconceptualizing anorexia nervosa. Psychiatry Clin Neurosci. 2019;73(9):518-25.

591 3. Mitchell JE, Peterson CB. Anorexia Nervosa. N Engl J Med. 2020 02;382(14):1343-51.

592 4. Chesney E, Goodwin GM, Fazel S. Risks of all-cause and suicide mortality in mental disorders: a 593 meta-review. World Psychiatry Off J World Psychiatr Assoc WPA. 2014 Jun;13(2):153-60.

5. Ulfvebrand S, Birgegård A, Norring C, Högdahl L, von Hausswolff-Juhlin Y. Psychiatric comorbidity in women and men with eating disorders results from a large clinical database. Psychiatry Res. 2015 Dec 15;230(2):294-9.

6. Root TL, Pinheiro AP, Thornton L, Strober M, Fernandez-Aranda F, Brandt H, et al. Substance use disorders in women with anorexia nervosa. Int J Eat Disord. 2010 Jan;43(1):14-21.

7. Raevuori A, Haukka J, Vaarala O, Suvisaari JM, Gissler M, Grainger M, et al. The increased risk for autoimmune diseases in patients with eating disorders. PloS One. 2014;9(8):e104845.

8. Hedman A, Breithaupt L, Hübel C, Thornton LM, Tillander A, Norring C, et al. Bidirectional relationship between eating disorders and autoimmune diseases. J Child Psychol Psychiatry. 2019;60(7):80312.

9. Anorexia Nervosa Genetics Initiative, Eating Disorders Working Group of the Psychiatric Genomics Consortium, Watson HJ, Yilmaz Z, Thornton LM, Hübel C, et al. Genome-wide association study identifies eight risk loci and implicates metabo-psychiatric origins for anorexia nervosa. Nat Genet. 2019 Aug;51(8):1207-14.

10. Yilmaz Z, Hardaway JA, Bulik CM. Genetics and Epigenetics of Eating Disorders. Adv Genomics Genet. 2015;5:131-50.

11. Levinson CA, Zerwas SC, Brosof LC, Thornton LM, Strober M, Pivarunas B, et al. Associations between dimensions of anorexia nervosa and obsessive-compulsive disorder: An examination of personality and psychological factors in patients with anorexia nervosa. Eur Eat Disord Rev J Eat Disord Assoc. 2019;27(2):161-72.

12. Kaye WH, Wierenga CE, Bailer UF, Simmons AN, Bischoff-Grethe A. Nothing tastes as good as skinny feels: the neurobiology of anorexia nervosa. Trends Neurosci. 2013 Feb 1;36(2):110-20.

13. Speakman JR, Levitsky DA, Allison DB, Bray MS, Castro JM de, Clegg DJ, et al. Set points, settling points and some alternative models: theoretical options to understand how genes and environments combine to regulate body adiposity. Dis Model Mech. 2011 Nov 1;4(6):733-45.

14. Müller MJ, Bosy-Westphal A, Heymsfield SB. Is there evidence for a set point that regulates human body weight? F1000 Med Rep [Internet]. 2010 Aug 9 [cited 2020 Oct 20];2. Available from: https://www.ncbi.nlm.nih.gov/pmc/articles/PMC2990627/

15. Hebebrand J, Muller TD, Holtkamp K, Herpertz-Dahlmann B. The role of leptin in anorexia nervosa: clinical implications. Mol Psychiatry. 2007 Jan;12(1):23-35. 
medRxiv preprint doi: https://doi.org/10.1101/2021.02.12.21250941; this version posted March 13, 2021. The copyright holder for this preprint (which was not certified by peer review) is the author/funder, who has granted medRxiv a license to display the preprint in perpetuity. It is made available under a CC-BY-NC-ND 4.0 International license .

624

625

626

627

628

629

630

631

632

633

634

635

636

637

638

639

640

641

642

643

644

645

646

647

648

649

650

651

652

653

654

655

656

657

658

659

660

661

662

16. Hübel C, Yilmaz Z, Schaumberg KE, Breithaupt L, Hunjan A, Horne E, et al. Body composition in anorexia nervosa: Meta-analysis and meta-regression of cross-sectional and longitudinal studies. Int J Eat Disord. 2019;52(11):1205-23.

17. Igudesman D, Sweeney M, Carroll IM, Mayer-Davis EJ, Bulik CM. Gut-Brain Interactions: Implications for a Role of the Gut Microbiota in the Treatment and Prognosis of Anorexia Nervosa and Comparison to Type I Diabetes. Gastroenterol Clin North Am. 2019;48(3):343-56.

18. Huckins LM, Hatzikotoulas K, Southam L, Thornton LM, Steinberg J, Aguilera-Mckay F, et al. Investigation of common, low-frequency and rare genome-wide variation in anorexia nervosa. Mol Psychiatry. 2018;23(5).

19. Huckins LM, Dobbyn A, McFadden W, Ruderfer D, Wang W, Gamazon E, et al. Identifying tissues implicated in Anorexia Nervosa using Transcriptomic Imputation. bioRxiv. 2018;265017.

20. Hinney A, Kesselmeier M, Jall S, Volckmar A-L, Föcker M, Antel J, et al. Evidence for three genetic loci involved in both anorexia nervosa risk and variation of body mass index. Mol Psychiatry. 2017;22(2).

21. Duncan L, Yilmaz Z, Gaspar H, Walters R, Goldstein J, Anttila V, et al. Significant Locus and Metabolic Genetic Correlations Revealed in Genome-Wide Association Study of Anorexia Nervosa. Am J Psychiatry. 2017 01;174(9):850-8.

22. Munn-Chernoff MA, Johnson EC, Chou Y-L, Coleman JRI, Thornton LM, Walters RK, et al. Shared genetic risk between eating disorder- and substance-use-related phenotypes: Evidence from genome-wide association studies. Addict Biol. 2020 Feb 16;e12880.

23. Hübel C, Gaspar HA, Coleman JRI, Finucane H, Purves KL, Hanscombe KB, et al. Genomics of body fat percentage may contribute to sex bias in anorexia nervosa. Am J Med Genet Part B Neuropsychiatr Genet Off Publ Int Soc Psychiatr Genet. 2019;180(6):428-38.

24. $\mathrm{C} \mathrm{H}, \mathrm{M} \mathrm{A}, \mathrm{M} \mathrm{H}, \mathrm{Rj} \mathrm{L}, \mathrm{G} \mathrm{B}, \mathrm{Cm} \mathrm{B}$, et al. Binge-eating disorder, anorexia nervosa, and constitutional thinness differ in their associations with anthropometric and psychiatric polygenic scores. 2020 Mar 26 [cited 2020 Aug 20]; Available from: https://europepmc.org/article/ppr/ppr126993

25. Smoller JW. The use of electronic health records for psychiatric phenotyping and genomics. Am J Med Genet Part B Neuropsychiatr Genet Off Publ Int Soc Psychiatr Genet. 2018;177(7):601-12.

26. Denny JC, Ritchie MD, Basford MA, Pulley JM, Bastarache L, Brown-Gentry K, et al. PheWAS: demonstrating the feasibility of a phenome-wide scan to discover gene-disease associations. Bioinforma Oxf Engl. 2010 May;26(9):1205-10.

27. Pendergrass SA, Brown-Gentry K, Dudek SM, Torstenson ES, Ambite JL, Avery CL, et al. The use of phenome-wide association studies (PheWAS) for exploration of novel genotype-phenotype relationships and pleiotropy discovery. Genet Epidemiol. 2011 Jul;35(5):410-22.

28. Zheutlin AB, Dennis J, Karlsson Linnér R, Moscati A, Restrepo N, Straub P, et al. Penetrance and Pleiotropy of Polygenic Risk Scores for Schizophrenia in 106,160 Patients Across Four Health Care Systems. Am J Psychiatry. 2019 Aug 16;176(10):846-55.

29. Leppert B, Millard LAC, Riglin L, Davey Smith G, Thapar A, Tilling K, et al. A cross-disorder PRSpheWAS of 5 major psychiatric disorders in UK Biobank. PLoS Genet. 2020 May;16(5):e1008185. 
medRxiv preprint doi: https://doi.org/10.1101/2021.02.12.21250941; this version posted March 13, 2021. The copyright holder for this preprint (which was not certified by peer review) is the author/funder, who has granted medRxiv a license to display the preprint in perpetuity. It is made available under a CC-BY-NC-ND 4.0 International license .

663

664

665

666

667

668

669

670

671

672

673

674

675

676

677

678

679

680

681

682

683

684

685

686

687

688

689

690

691

692

693

694

695

696

697

698

699

700

701

702

30. Denny JC, Bastarache L, Ritchie MD, Carroll RJ, Zink R, Mosley JD, et al. Systematic comparison of phenome-wide association study of electronic medical record data and genome-wide association study data. Nat Biotechnol. 2013 Dec;31(12):1102-10.

31. Lonsdale J, Thomas J, Salvatore M, Phillips R, Lo E, Shad S, et al. The Genotype-Tissue Expression (GTEx) project. Nat Genet. 2013 Jun;45(6):580-5.

32. Hoffman GE, Bendl J, Voloudakis G, Montgomery KS, Sloofman L, Wang Y-C, et al. CommonMind Consortium provides transcriptomic and epigenomic data for Schizophrenia and Bipolar Disorder. Sci Data. 2019 Sep 24;6(1):180.

33. Battle A, Mostafavi S, Zhu X, Potash JB, Weissman MM, McCormick C, et al. Characterizing the genetic basis of transcriptome diversity through RNA-sequencing of 922 individuals. Genome Res. 2014 Jan;24(1):14-24.

34. Gamazon ER, Wheeler HE, Shah KP, Mozaffari SV, Aquino-Michaels K, Carroll RJ, et al. A genebased association method for mapping traits using reference transcriptome data. Nat Genet. 2015 Sep;47(9):1091-8.

35. Barbeira AN, Dickinson SP, Bonazzola R, Zheng J, Wheeler HE, Torres JM, et al. Exploring the phenotypic consequences of tissue specific gene expression variation inferred from GWAS summary statistics. Nat Commun. 2018 May 8;9(1):1825.

36. Huckins LM, Dobbyn A, Ruderfer DM, Hoffman G, Wang W, Pardiñas AF, et al. Gene expression imputation across multiple brain regions provides insights into schizophrenia risk. Nat Genet. 2019;51(4):659-74.

37. Purcell S, Neale B, Todd-Brown K, Thomas L, Ferreira MAR, Bender D, et al. PLINK: a tool set for whole-genome association and population-based linkage analyses. Am J Hum Genet. 2007 Sep;81(3):559-75.

38. Chang CC, Chow CC, Tellier LC, Vattikuti S, Purcell SM, Lee JJ. Second-generation PLINK: rising to the challenge of larger and richer datasets. GigaScience. 2015;4:7.

39. Fromer M, Roussos P, Sieberts SK, Johnson JS, Kavanagh DH, Perumal TM, et al. Gene expression elucidates functional impact of polygenic risk for schizophrenia. Nat Neurosci. 2016;19(11):1442-53.

40. PheWAS/PheWAS [Internet]. PheWAS; 2019 [cited 2019 Nov 26]. Available from: https://github.com/PheWAS/PheWAS

41. Willer CJ, Li Y, Abecasis GR. METAL: fast and efficient meta-analysis of genomewide association scans. Bioinformatics. 2010 Sep 1;26(17):2190-1.

42. Verma A, Bradford Y, Dudek S, Lucas AM, Verma SS, Pendergrass SA, et al. A simulation study investigating power estimates in phenome-wide association studies. BMC Bioinformatics. $2018 \mathrm{Apr}$ $4 ; 19(1): 120$.

43. Wu P, Gifford A, Meng X, Li X, Campbell H, Varley T, et al. Developing and Evaluating Mappings of ICD-10 and ICD-10-CM Codes to PheCodes. bioRxiv. 2019 Jul 3;462077.

44. de Lange KM, Moutsianas L, Lee JC, Lamb CA, Luo Y, Kennedy NA, et al. Genome-wide association study implicates immune activation of multiple integrin genes in inflammatory bowel disease. Nat Genet. 2017 Feb;49(2):256-61. 
medRxiv preprint doi: https://doi.org/10.1101/2021.02.12.21250941; this version posted March 13, 2021. The copyright holder for this preprint (which was not certified by peer review) is the author/funder, who has granted medRxiv a license to display the preprint in perpetuity. It is made available under a CC-BY-NC-ND 4.0 International license .

703

704

705

706

707

708

709

710

711

712

713

714

715

716

717

718

719

720

721

722

723

724

725

726

727

728

729

730

731

732

733

734

735

736

737

738

739

740

741

742

45. Mårild K, Størdal K, Bulik CM, Rewers M, Ekbom A, Liu E, et al. Celiac Disease and Anorexia Nervosa: A Nationwide Study. Pediatrics. 2017 May;139(5).

46. S Z, Jt L, L P, Lm T, M Q, Sv K, et al. Eating Disorders, Autoimmune, and Autoinflammatory Disease. Pediatrics [Internet]. 2017 Nov 9 [cited 2020 Nov 16];140(6). Available from: https://europepmc.org/article/med/29122972

47. Gibson D, Mehler PS. Anorexia Nervosa and the Immune System-A Narrative Review. J Clin Med. 2019 Nov;8(11):1915.

48. Stahl EA, Breen G, Forstner AJ, McQuillin A, Ripke S, Trubetskoy V, et al. Genome-wide association study identifies 30 loci associated with bipolar disorder. Nat Genet. 2019 May;51(5):793.

49. Schizophrenia Working Group of the Psychiatric Genomics Consortium. Biological insights from 108 schizophrenia-associated genetic loci. Nature. 2014 Jul;511(7510):421-7.

50. The Autism Spectrum Disorders Working Group of The Psychiatric Genomics Consortium. Metaanalysis of GWAS of over 16,000 individuals with autism spectrum disorder highlights a novel locus at 10q24.32 and a significant overlap with schizophrenia. Mol Autism. 2017 Dec;8(1):21.

51. Zhu Z, Zhu X, Liu C-L, Shi H, Shen S, Yang Y, et al. Shared genetics of asthma and mental health disorders: a large-scale genome-wide cross-trait analysis. Eur Respir J [Internet]. 2019 Dec 1 [cited 2020 May 21];54(6). Available from: https://erj.ersjournals.com/content/54/6/1901507-0

52. Marchese S, Hoffman G, Pietrzak RH, Lebovitch D, Daskalakis NP, Yehuda R, et al. Altered gene expression and PTSD symptom dimensions in World Trade Center responders. In Prep. 2020;

53. Baselmans BML, Jansen $\mathrm{R}$, Ip HF, van Dongen J, Abdellaoui A, van de Weijer MP, et al. Multivariate Genome-wide and integrated transcriptome and epigenome-wide analyses of the Wellbeing spectrum [Internet]. Genetics; 2017 Mar [cited 2020 May 21]. Available from: http://biorxiv.org/lookup/doi/10.1101/115915

54. Yang X, Sun J, Gao Y, Tan A, Zhang H, Hu Y, et al. Genome-Wide Association Study for Serum Complement C3 and C4 Levels in Healthy Chinese Subjects. PLOS Genet. 2012 Sep 13;8(9):e1002916.

55. Sekar A, Bialas AR, de Rivera H, Davis A, Hammond TR, Kamitaki N, et al. Schizophrenia risk from complex variation of complement component 4. Nature. 2016;530(7589):177-83.

56. Stephan AH, Barres BA, Stevens B. The complement system: an unexpected role in synaptic pruning during development and disease. Annu Rev Neurosci. 2012;35:369-89.

57. Li B, Mao Y, Wang Z, Chen Y, Wang Y, Zhai C, et al. CLIC1 Promotes the Progression of Gastric Cancer by Regulating the MAPK/AKT Pathways. Cell Physiol Biochem. 2018;46(3):907-24.

58. Carlini V, Verduci I, Cianci F, Cannavale G, Fenoglio C, Galimberti D, et al. CLIC1 Protein Accumulates in Circulating Monocyte Membrane during Neurodegeneration. Int J Mol Sci. 2020 Jan;21(4):1484.

59. Facal F, Costas J. Evidence of association of the DISC1 interactome gene set with schizophrenia from GWAS. Prog Neuropsychopharmacol Biol Psychiatry. 2019 20;95:109729.

60. Milton RH, Abeti R, Averaimo S, DeBiasi S, Vitellaro L, Jiang L, et al. CLIC1 function is required for beta-amyloid-induced generation of reactive oxygen species by microglia. J Neurosci Off $\mathrm{J}$ Soc Neurosci. 2008 Nov 5;28(45):11488-99. 
medRxiv preprint doi: https://doi.org/10.1101/2021.02.12.21250941; this version posted March 13, 2021. The copyright holder for this preprint (which was not certified by peer review) is the author/funder, who has granted medRxiv a license to display the preprint in perpetuity. It is made available under a CC-BY-NC-ND 4.0 International license .

743

744

745

746

747

748

749

750

751

752

753

754

755

756

757

758

759

760

761

762

763

764

765

766

767

768

769

770

771

772

773

774

775

776

777

778

779

780

781

782

61. Novarino G, Fabrizi C, Tonini R, Denti MA, Malchiodi-Albedi F, Lauro GM, et al. Involvement of the intracellular ion channel CLIC1 in microglia-mediated beta-amyloid-induced neurotoxicity. J Neurosci Off J Soc Neurosci. 2004 Jun 9;24(23):5322-30.

62. Swarup V, Chang TS, Duong DM, Dammer EB, Dai J, Lah JJ, et al. Identification of Conserved Proteomic Networks in Neurodegenerative Dementia. Cell Rep. 2020 Jun 23;31(12):107807.

63. Lee YH, Bae S-C, Choi SJ, Ji JD, Song GG. Genome-wide pathway analysis of genome-wide association studies on systemic lupus erythematosus and rheumatoid arthritis. Mol Biol Rep. 2012 Dec 1;39(12):10627-35.

64. Nilsson IAK, Millischer V, Göteson A, Hübel C, Thornton LM, Bulik CM, et al. Aberrant inflammatory profile in acute but not recovered anorexia nervosa. Brain Behav Immun. 2020 Aug 1;88:718-24.

65. Bulik CM. Genetic and Biological Risk Factors. In: Thompson JK, editor. Handbook of Eating Disorders and Obesity [Internet]. Hoboken, NJ: Wiley; 2004. p. 3. Available from:

https://books.google.com/books/about/Handbook\%7B_\%7Dof\%7B_\%7DEating\%7B_\%7DDisorders \%7B_\%7Dand\%7B_\%7DObesity.html?id=KZhHAAAAMAAJ\%7B\&\%7Dpgis=1

66. Shroff H, Reba L, Thornton LM, Tozzi F, Klump KL, Berrettini WH, et al. Features associated with excessive exercise in women with eating disorders. Int J Eat Disord. 2006 Sep;39(6):454-61.

67. Achamrah N, Coëffier M, Déchelotte P. Physical activity in patients with anorexia nervosa. Nutr Rev. 2016 May 1;74(5):301-11.

68. Strober M, Freeman R, Morrell W. The long-term course of severe anorexia nervosa in adolescents: Survival analysis of recovery, relapse, and outcome predictors over 10-15 years in a prospective study. Int J Eat Disord. 1997;22(4):339-60.

69. Hübel C, Gaspar HA, Coleman JRI, Hanscombe KB, Purves K, Prokopenko I, et al. Genetic correlations of psychiatric traits with body composition and glycemic traits are sex- and agedependent. Nat Commun. 2019 18;10(1):5765.

70. Solmi M, Veronese N, Correll CU, Favaro A, Santonastaso P, Caregaro L, et al. Bone mineral density, osteoporosis, and fractures among people with eating disorders: a systematic review and meta-analysis. Acta Psychiatr Scand. 2016 May;133(5):341-51.

71. Etain B, Jamain S, Milhiet V, Lajnef M, Boudebesse C, Dumaine A, et al. Association between circadian genes, bipolar disorders and chronotypes. Chronobiol Int. 2014 Aug;31(7):807-14.

72. Melo MCA, Abreu RLC, Linhares Neto VB, de Bruin PFC, de Bruin VMS. Chronotype and circadian rhythm in bipolar disorder: A systematic review. Sleep Med Rev. 2017 Aug;34:46-58.

73. Huckins L, Dobbyn A, McFadden W, Wang W, Ruderfer D, Hoffman G, et al. Transcriptomic Imputation of Bipolar Disorder and Bipolar subtypes reveals 29 novel associated genes. bioRxiv. 2017 Nov;222786.

74. Meyrer R, Demling J, Kornhuber J, Nowak M. Effects of night shifts in bipolar disorders and extreme morningness. Bipolar Disord. 2009 Dec;11(8):897-9.

75. Alloy LB, Ng TH, Titone MK, Boland EM. Circadian Rhythm Dysregulation in Bipolar Spectrum Disorders. Curr Psychiatry Rep. 2017 Apr;19(4):21.

76. Boivin DB. Influence of sleep-wake and circadian rhythm disturbances in psychiatric disorders. J Psychiatry Neurosci JPN. 2000 Nov;25(5):446-58. 
medRxiv preprint doi: https://doi.org/10.1101/2021.02.12.21250941; this version posted March 13, 2021. The copyright holder for this preprint (which was not certified by peer review) is the author/funder, who has granted medRxiv a license to display the preprint in perpetuity. It is made available under a CC-BY-NC-ND 4.0 International license .

783

784

785

786

787

788

789

790

791

792

793

794

795

796

797

798

799

800

801

802

803

804

805

806

807

808

809

810

811

812

813

814

815

816

817

818

819

820

77. Bunney BG, Bunney WE. Mechanisms of Rapid Antidepressant Effects of Sleep Deprivation Therapy: Clock Genes and Circadian Rhythms. Biol Psychiatry. 2013 Jun;73(12):1164-71.

78. Bunney BG, Li JZ, Walsh DM, Stein R, Vawter MP, Cartagena P, et al. Circadian dysregulation of clock genes: clues to rapid treatments in major depressive disorder. Mol Psychiatry. 2015 Feb;20(1):48-55.

79. Karatsoreos IN. Links between Circadian Rhythms and Psychiatric Disease. Front Behav Neurosci. 2014;8:162.

80. Kripke DF, Mullaney DJ, Atkinson M, Wolf S. Circadian rhythm disorders in manic-depressives. Biol Psychiatry. 1978 Jun;13(3):335-51.

81. Mansour HA, Talkowski ME, Wood J, Chowdari KV, McClain L, Prasad K, et al. Association study of 21 circadian genes with bipolar I disorder, schizoaffective disorder, and schizophrenia. Bipolar Disord. 2009 Nov;11(7):701-10.

82. Murray G, Allen NB, Trinder J, Burgess $\mathrm{H}$. Is weakened circadian rhythmicity a characteristic of neuroticism? J Affect Disord. 2002 Dec;72(3):281-9.

83. Allison KC, Spaeth A, Hopkins CM. Sleep and Eating Disorders. Curr Psychiatry Rep. 2016;18(10):92.

84. Arble DM, Bass J, Laposky AD, Vitaterna MH, Turek FW. Circadian timing of food intake contributes to weight gain. Obesity. 2009;17(11):2100-2.

85. Herpertz S, Albers N, Wagner R, Pelz B, Köpp W, Mann K, et al. Longitudinal changes of circadian leptin, insulin and cortisol plasma levels and their correlation during refeeding in patients with anorexia nervosa. Eur J Endocrinol. 2000 Apr;142(4):373-9.

86. Zucker NL, Bulik CM. On bells, saliva, and abdominal pain or discomfort: Early aversive visceral conditioning and vulnerability for anorexia nervosa. Int J Eat Disord. 2020;53(4):508-12.

87. Adams DM, Reay WR, Geaghan MP, Cairns MJ. Investigation of glycaemic traits in psychiatric disorders using Mendelian randomisation revealed a causal relationship with anorexia nervosa. Neuropsychopharmacology. 2020 Sep 13;1-10.

88. Ilyas A, Hübel C, Stahl D, Stadler M, Ismail K, Breen G, et al. The metabolic underpinning of eating disorders: A systematic review and meta-analysis of insulin sensitivity. Mol Cell Endocrinol. 2019 Nov 1;497:110307.

89. Abdulkadir M, Herle M, De Stavola BL, Hübel C, Santos Ferreira DL, Loos RJF, et al. Polygenic Score for Body Mass Index Is Associated with Disordered Eating in a General Population Cohort. J Clin Med [Internet]. 2020 Apr 21 [cited 2020 Nov 3];9(4). Available from: https://www.ncbi.nlm.nih.gov/pmc/articles/PMC7231239/

90. Nagata JM, Braudt DB, Domingue BW, Bibbins-Domingo K, Garber AK, Griffiths S, et al. Genetic risk, body mass index, and weight control behaviors: Unlocking the triad. Int J Eat Disord. 2019;52(7):825-33.

91. Kolb R, Sutterwala FS, Zhang W. Obesity and cancer: inflammation bridges the two. Curr Opin Pharmacol. 2016 Aug 1;29:77-89. 
medRxiv preprint doi: https://doi.org/10.1101/2021.02.12.21250941; this version posted March 13, 2021. The copyright holder for this preprint (which was not certified by peer review) is the author/funder, who has granted medRxiv a license to display the preprint in perpetuity. It is made available under a CC-BY-NC-ND 4.0 International license.

821 92. Wiklund CA, Kuja-Halkola R, Thornton LM, Hübel C, Leppä V, Bulik CM. Prolonged constipation and diarrhea in childhood and disordered eating in adolescence. J Psychosom Res. 2019;126:109797.

824 93. Riedlinger C, Schmidt G, Weiland A, Stengel A, Giel KE, Zipfel S, et al. Which Symptoms, Complaints and Complications of the Gastrointestinal Tract Occur in Patients With Eating Disorders? A Systematic Review and Quantitative Analysis. Front Psychiatry. 2020;11:195. 


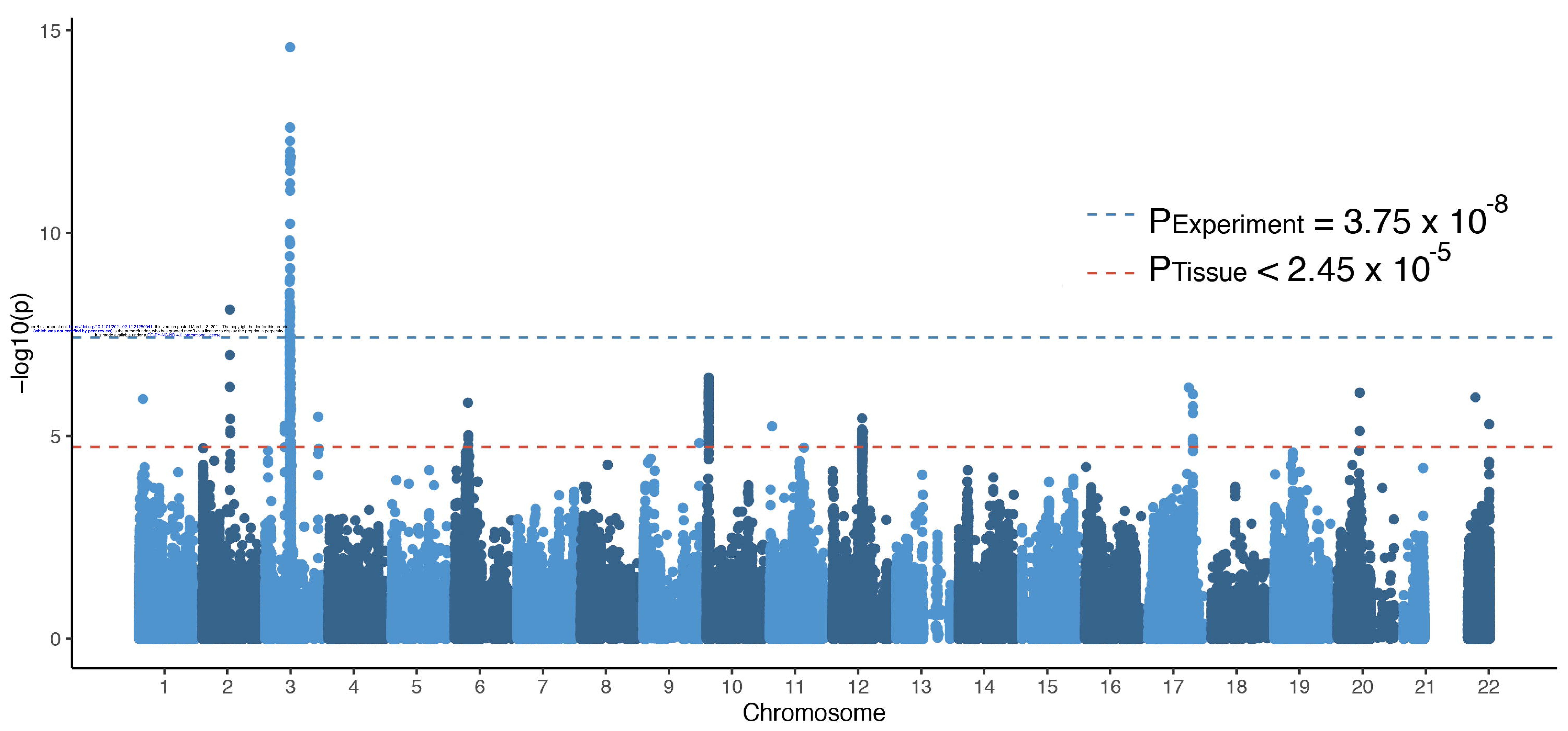


Highest Recorded Weight (kg)

CLIC1-Breast Mammary Tissue

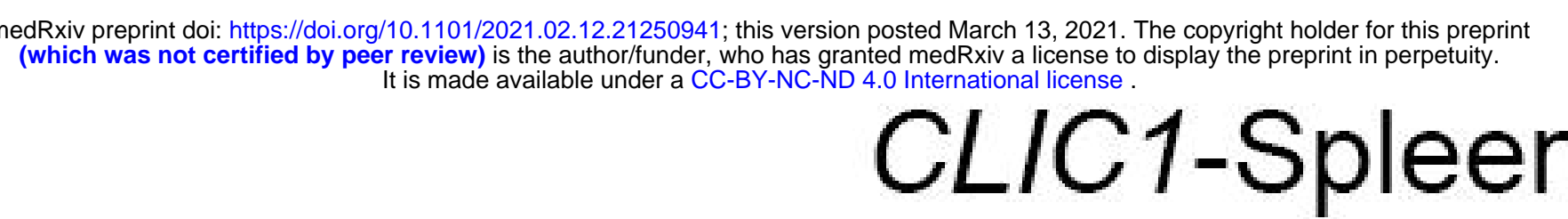

CLIC1-Spleen

CTNNB1-Colon Transverse

CLIC1-Whole Blood

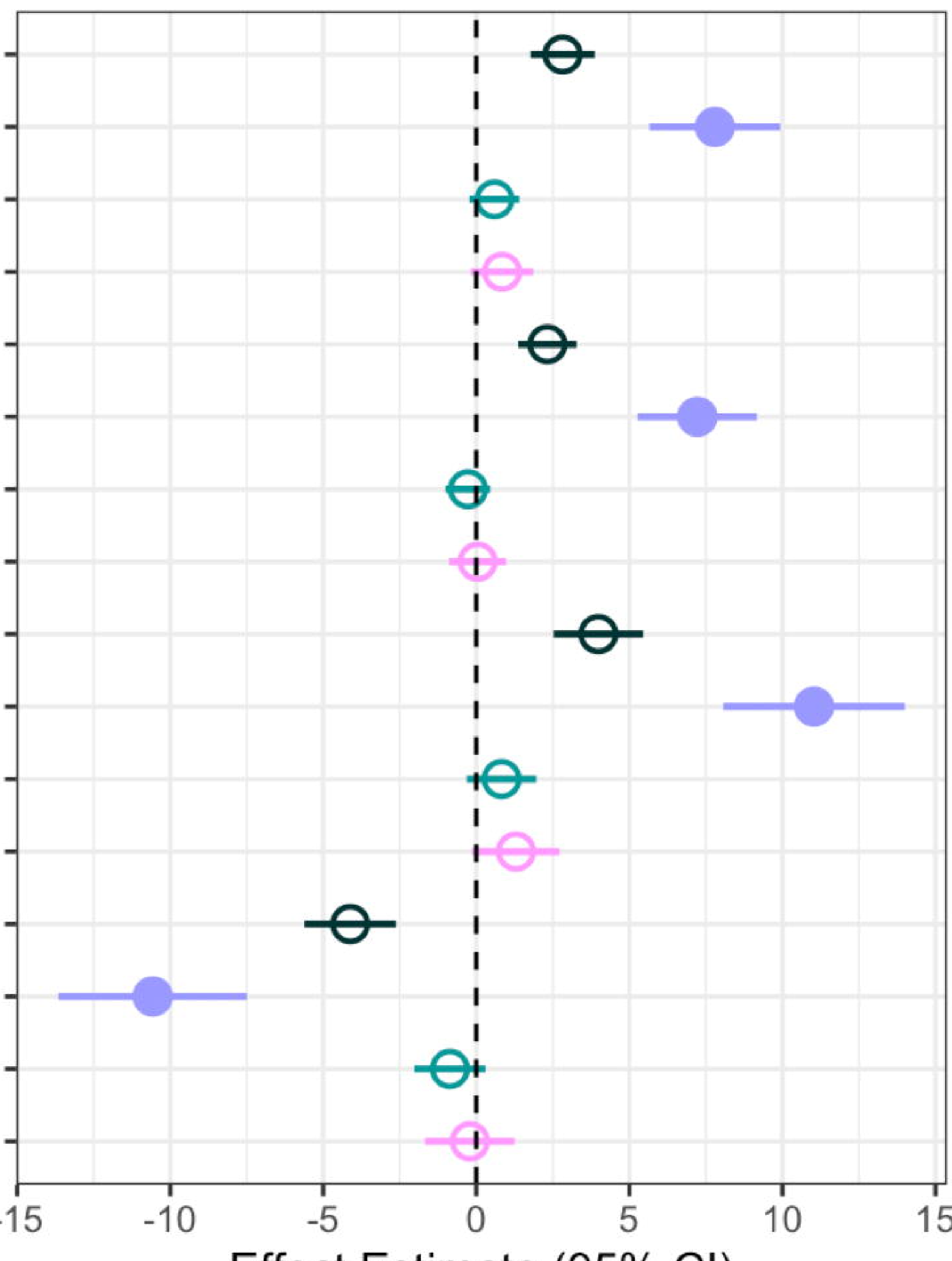

Effect Estimate $(95 \% \mathrm{Cl})$

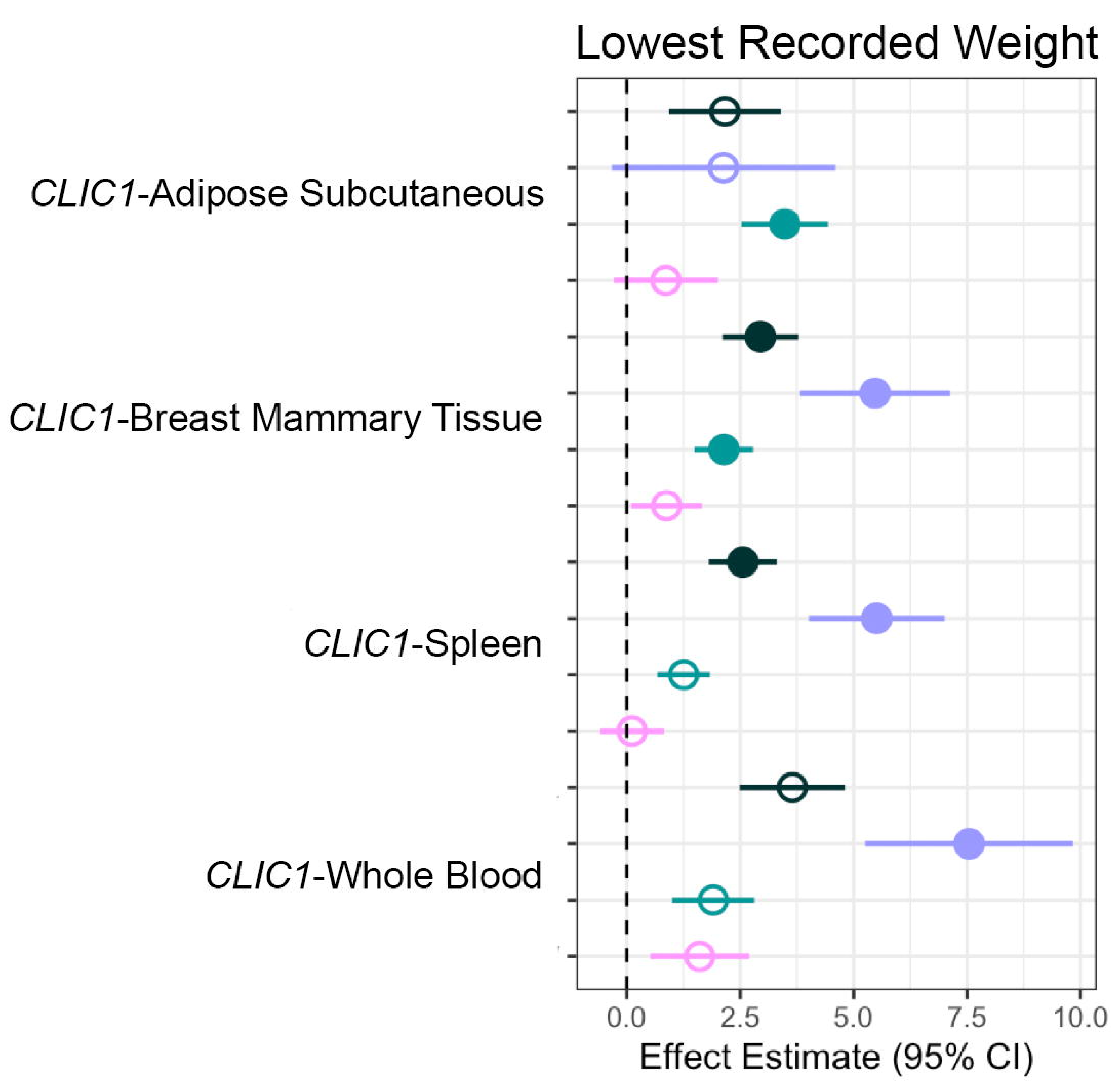

BMI Group

o overall

HIGH

MID

Low

Significant

NS 


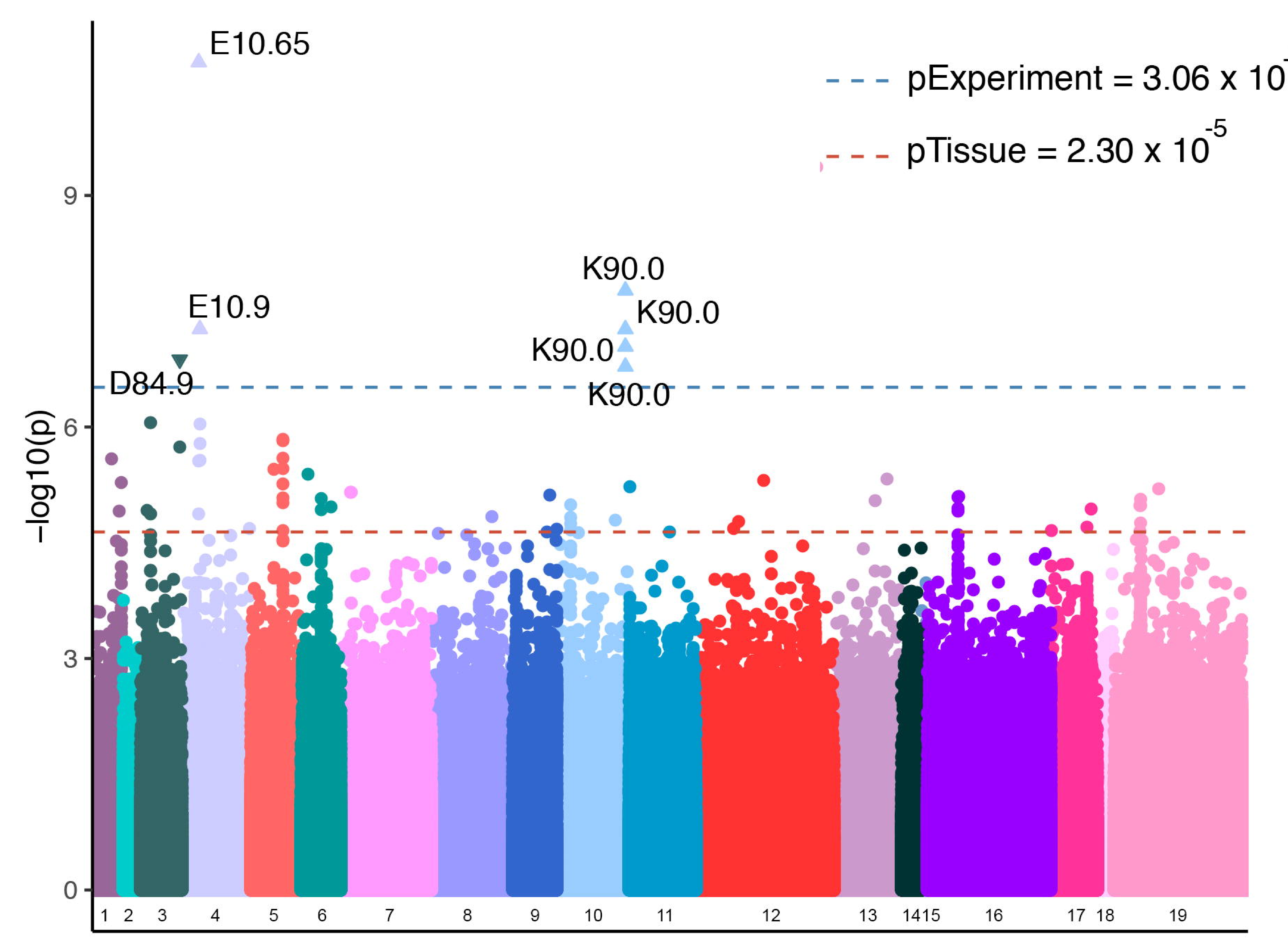

Encounter Diagnosis Groups

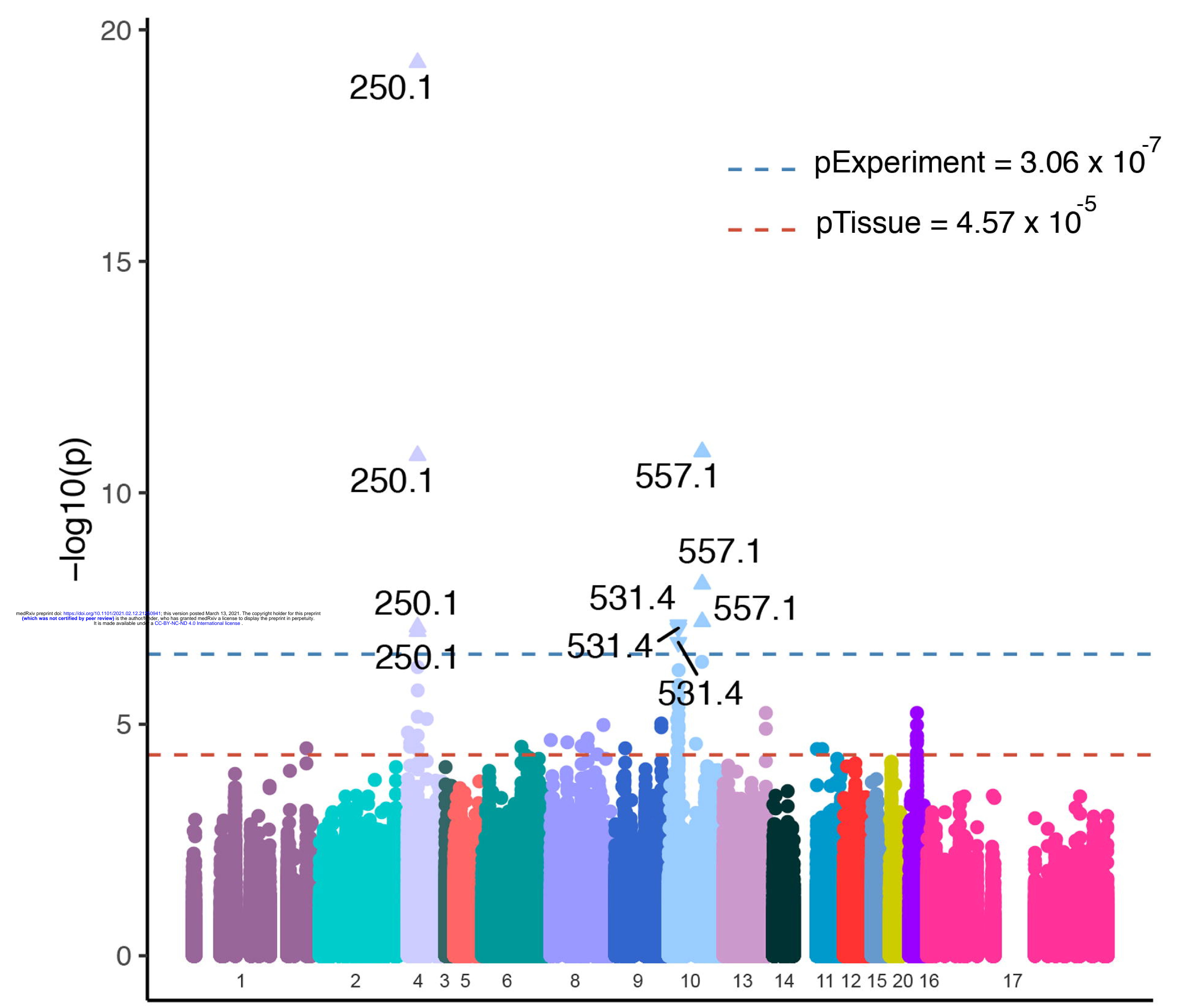

Phecode

\section{Diagnosis Group}

1 Infectious and parasitic

2 Neoplasms

3 Blood disorders

4 Endocrine/Nutritional/Metabolic

5 Mental/Behavioral/Neurodevelopmental

6 Nervous system

7 Eye/Ear

8 Circulatory system

9 Respiratory system

10 Digestive system

11 Skin/Subcutaneous tissue

- 12 Musculoskeletal system/Connective tissue

13 Genitourinary system

- 14 Pregnancy/Childbirth/Puerperium

- 15 Congenital abnormalities

- 16 Symptoms/signs

17 Injury/poisoning

18 External causes of morbidity

19 Factors influencing health status

20 Conditions originating in the perinatal period

Direction of effect

$\checkmark$ DOWN

$\triangle$ UP 
i. Overall

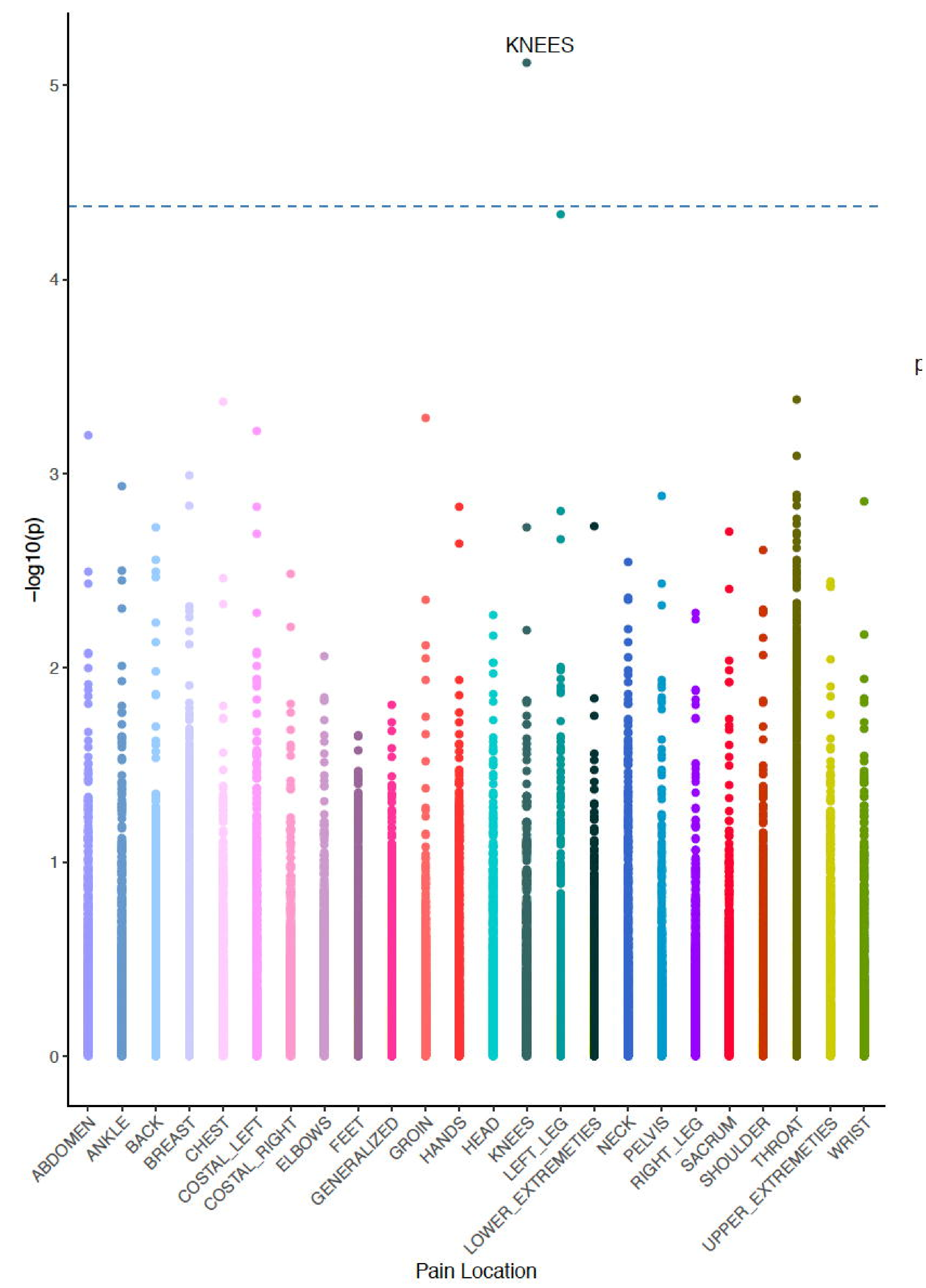

iii. Mid BMI

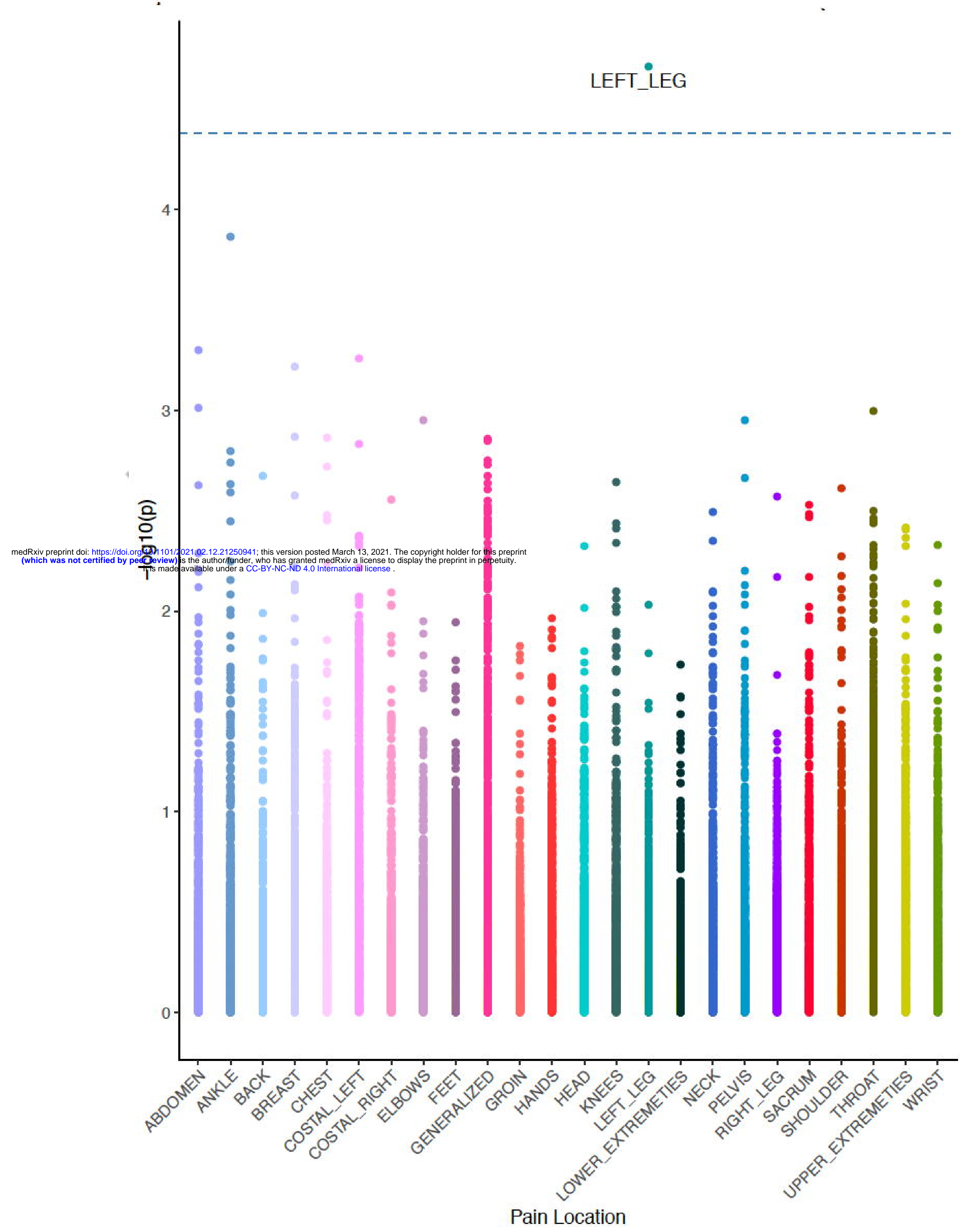

ii. High BMI

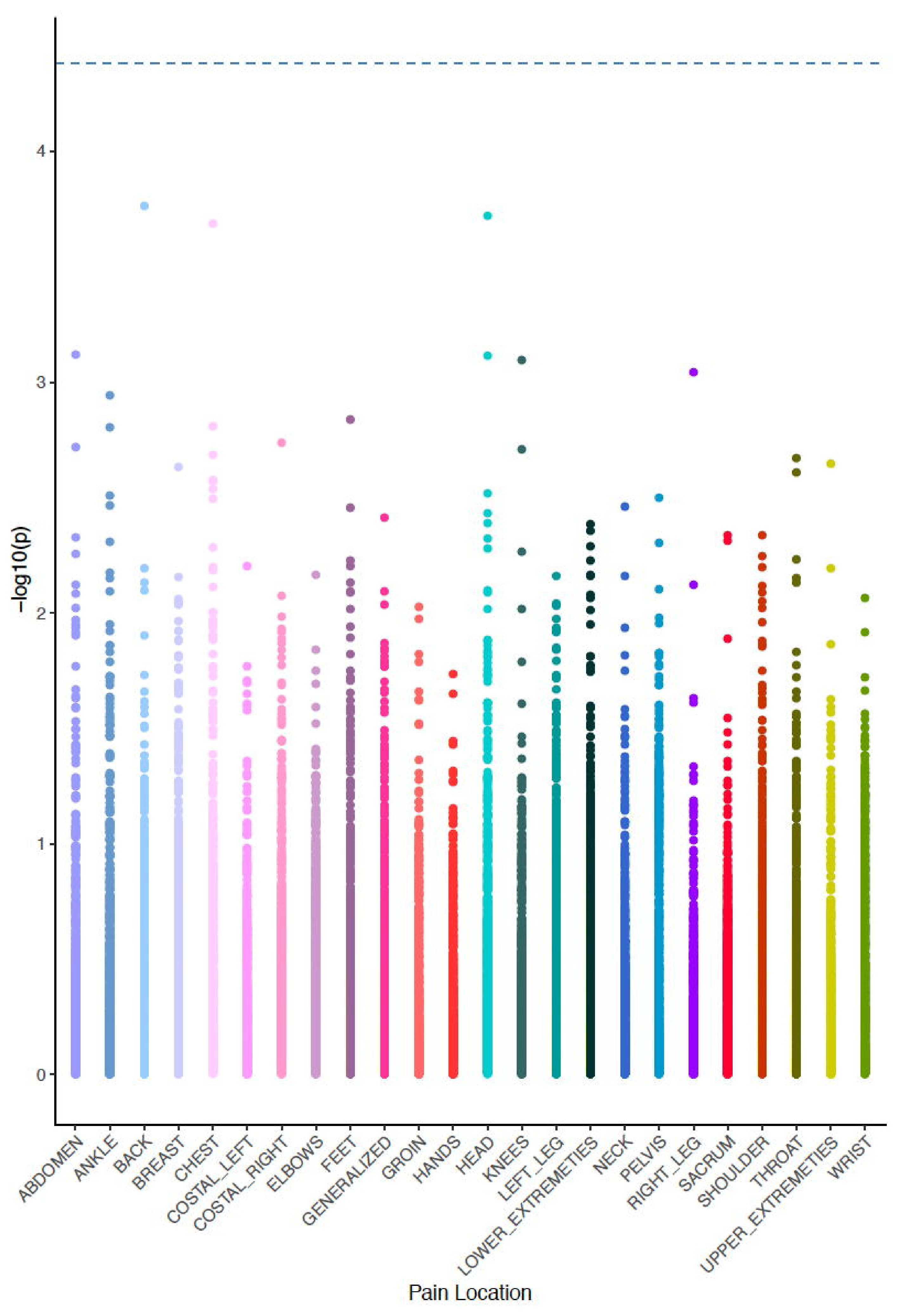

iv. Low BMI

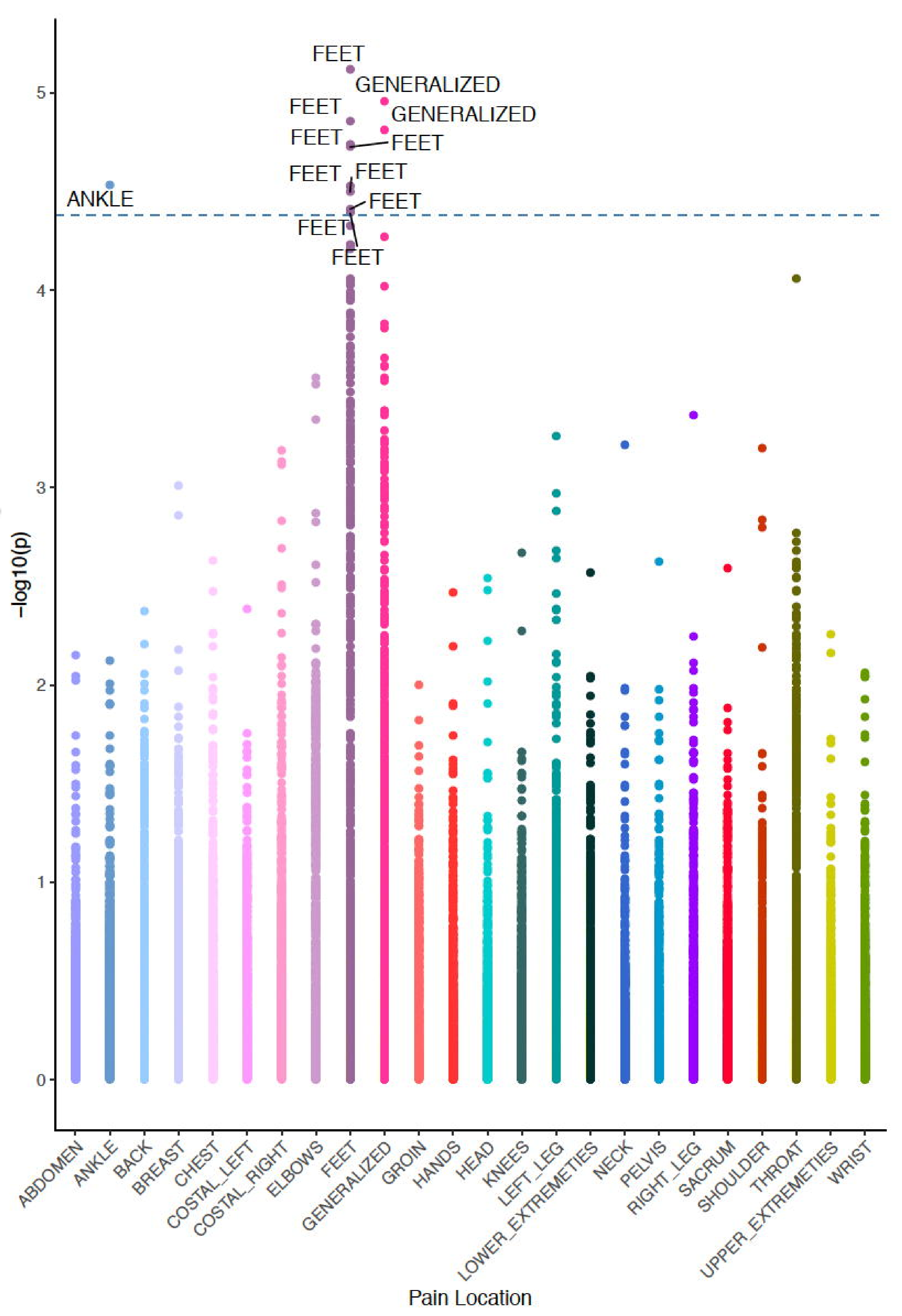




\section{BioMe BioBank Demographic Information}

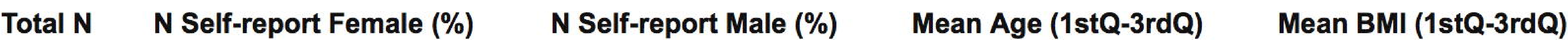

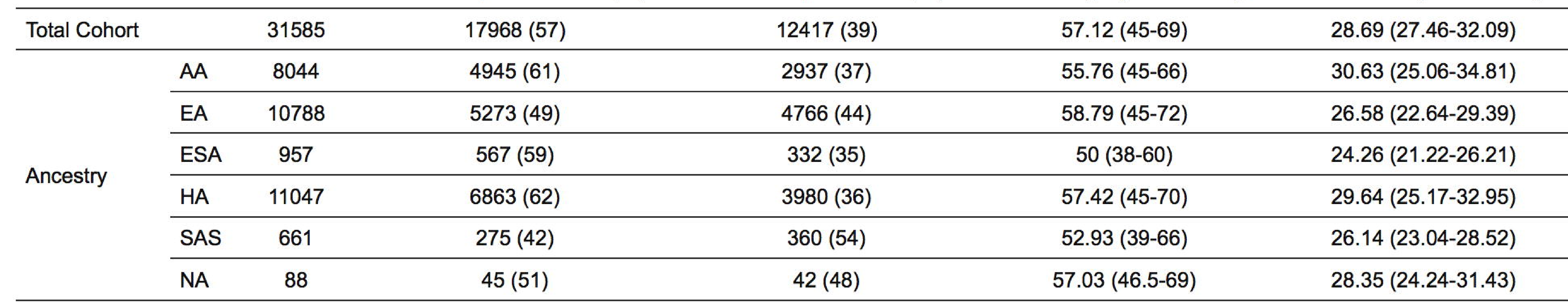




\begin{tabular}{|c|c|c|c|c|c|}
\hline Chromosome & Genes & Zscore & P-value & $\begin{array}{c}\text { Top } \\
\text { Finding } \\
\text { (Gene) }\end{array}$ & Top Finding (Tissue) \\
\hline \multicolumn{2}{|c|}{ 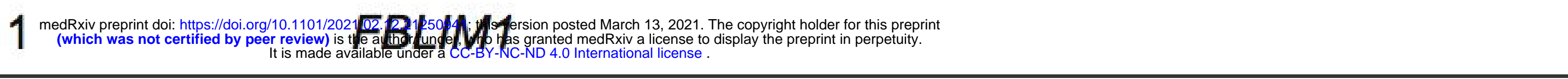 } & -4.851060 & $1.23 e-06$ & FBLIM1 & Liver \\
\hline 2 & ASB3, CHAC2, GPR75 & -5.780228 & $7.46 e-09$ & GPR75 & Whole_Blood \\
\hline 3 & $\begin{array}{l}\text { SPINK8, PFKFB4, TMEM89, SLC26A6, CELSR3, } \\
\text { NCKIPSD, ARIH2OS, ARIH2, P4HTM, WDR6, DALRD3, } \\
\text { NDUFAF3, USP19, LAMB2, CCDC71, CCDC36, C3orf62, } \\
\text { GPX1, NICN1, DAG1, APEH, MST1, MST1R, RNF123, } \\
\text { RBM6, RBM5, SEMA3F, TUSC2 }\end{array}$ & 7.321127 & $2.46 e-13$ & WDR6 & Skin_Sun_Exposed_Lower_leg \\
\hline 3 & PROS1, DHFRL1 & 4.687382 & $2.77 e-06$ & DHFRL1 & DGN_Whole_Blood \\
\hline 6 & CLIC1 & 4.814629 & $1.47 e-06$ & $C L I C 1$ & Nerve_Tibial \\
\hline 10 & MGMT, EBF3 & -5.086391 & $3.65 e-07$ & MGMT & Thyroid \\
\hline 11 & ARNTL & 4.534957 & $5.76 e-06$ & ARNTL & Whole_Blood \\
\hline 12 & SUOX, RPS26, SLC26A10 & 4.628307 & $3.69 \mathrm{e}-06$ & $R P S 26$ & Uterus \\
\hline 17 & TNFSF12, LINC00324 & 4.982641 & $6.27 e-07$ & TNFSF12 & Breast_Mammary_Tissue \\
\hline 20 & $S L C 2 A 10$ & 4.921176 & $8.60 \mathrm{e}-07$ & $S L C 2 A 10$ & Nerve_Tibial \\
\hline 22 & KREMEN1 & 4.872670 & $1.10 \mathrm{e}-06$ & KREMEN1 & Nerve_Tibial \\
\hline 22 & SCO2 & -4.560015 & $5.11 e-06$ & SCO2 & Brain_Cerebellum \\
\hline
\end{tabular}

